\title{
Pre- and probiotics for allergy prevention: time to revisit recommendations?
}

\author{
Anna Forsberg, C. E. West, S. L. Prescott and Maria Jenmalm \\ Journal Article
}

\section{Tweet}

N.B.: When citing this work, cite the original article.

Original Publication:

Anna Forsberg, C. E. West, S. L. Prescott and Maria Jenmalm, Pre- and probiotics for allergy prevention: time to revisit recommendations?, Clinical and Experimental Allergy, 2016. 46(12), pp.1506-1521.

http://dx.doi.org/10.1111/cea.12838

Copyright: Wiley: 12 months

http://eu.wiley.com/WileyCDA/

Postprint available at: Linköping University Electronic Press

http://urn.kb.se/resolve?urn=urn:nbn:se:liu:diva-133736

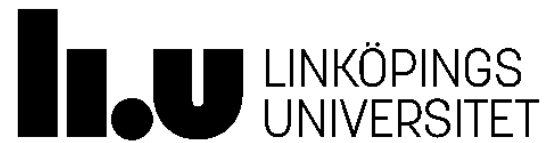


Received Date : 01-Jun-2016

Revised Date : 04-Sep-2016

Accepted Date : 04-Oct-2016

Article type : Invited Review

\title{
Pre- and probiotics for allergy prevention: time to revisit recommendations?
}

\author{
${ }^{1}$ Forsberg, A. ${ }^{2,3}$ West, C.E. ${ }^{2,4}$ Prescott, S.L ${ }^{1,2}$ Jenmalm, M.C.
}

${ }^{1}$ Division of Neuro and Inflammation Sciences, Department of Clinical and Experimental Medicine, Linköping University, Linköping, Sweden

${ }^{2}$ International Inflammation (in-FLAME) network of the World Universities Network

${ }^{3}$ Department of Clinical Sciences, Pediatrics, Umeå University, Umeå, Sweden

${ }^{4}$ School of Paediatrics and Child Health, University of Western Australia and Princess Margaret Hospital for Children, Perth, Australia

Correspondence to: Maria Jenmalm, PhD, Professor

Dept of Clinical \& Experimental Medicine / AIR pl 10

Faculty of Medicine and Health Sciences, Linköping University

SE-581 85 Linköping

Sweden

Phone: +46-10-103 4101

Fax: +46-13-13 2257

e-mail: maria.jenmalm@liu.se

\section{Abstract}

Reduced intensity and diversity of microbial exposure is considered a major factor driving abnormal postnatal immune maturation and increasing allergy prevalence, particularly in more affluent regions. Quantitatively the largest important source of early immune-microbial interaction, the gut microbiota is of particular interest in this context, with variations in composition and diversity in the first months of life associated with subsequent allergy development. Attempting to restore the health consequences of the 'dysbiotic drift' in modern society, interventions modulating gut microbiota for allergy prevention have been evaluated in several randomized placebo controlled trials. In this review, we provide an 
overview of these trials and discuss recommendations from international expert bodies regarding prebiotic, probiotic and synbiotic interventions. Recent guidelines from the World Allergy Organization recommend the use of probiotics for the primary prevention of eczema in pregnant and breastfeeding mothers of infants at high risk for developing allergy and in high risk infants. It is however stressed that these recommendations are conditional, based on very low quality evidence and great heterogeneity between studies, which also impedes specific and practical advice to consumers on the most effective regimens. We discuss how the choice of probiotic strains, timing and duration of administration can critically influence the outcome due to different effects on immune modulation and gut microbiota composition. Furthermore, we propose strategies to potentially improve allergy preventive effects and enable future evidence-based implementation.

\section{Introduction}

The increasing allergy prevalence in affluent countries has been striking. While this is likely to be multi-factorial, reduced intensity and diversity of microbial stimulation are possible major factors promoting abnormal postnatal immune maturation [1, 2]. In support of this hypothesis, children who later develop allergic disease show differences in the composition and diversity of their gut microbiota during the first months of life compared with those who do not [3-14]. Accordingly, interventions to modulate the gut microbiota have been of key interest as potential allergy preventive strategies, and have now been evaluated in a series of double blind placebo controlled randomised trials [15-17]. Here, we provide an overview of the results of these trials, discuss recent recommendations that have arisen as a result of these microbiota modulating interventions, highlight potential immunomodulatory mechanisms and propose future strategies to confirm and potentially improve allergy preventive effects.

\section{Primary prevention studies using probiotics}

\section{Eczema}

Several randomized controlled trials (RCTs) have examined the effects of probiotics, defined as "live microorganisms which when ingested in adequate amounts confer a beneficial effect 
on the host" [18], for primary prevention of early manifestations of allergic diseases, e.g. eczema and IgE-associated eczema [19-34] (Table 1). As shown in Table 1, the probiotic preparations used have generally included strains of lactobacilli and bifidobacteria, either as single strains or in combination. Long-term follow-up data that include respiratory outcomes as well have been reported from some [35-43] but not all studies, as several are still ongoing (Table 1).

Two meta-analyses published in 2015 concluded that there is a benefit of probiotics for primary prevention of eczema, but not for any other allergic manifestations [16, 44]. Zuccotti et al [44] included 17 studies (4755 children) in their meta-analysis and found that treatment with probiotics led to a significantly lower relative risk (RR) for eczema compared with placebo (RR 0.78; 95\% Cl: 0.69-0.89), and that the effect was most pronounced when a combination of probiotic strains was used (RR $0.54 ; 95 \% \mathrm{Cl}$ : $0.43-0.68)$. No benefit of probiotics was found for wheeze, asthma or rhinoconjunctivitis. Cuello-Garcia et al [16] identified and included 29 studies in their meta-analysis, although some of these were follow-up studies of non-unique populations, and evaluated the effects according to timing and method of probiotic administration. Probiotics were reported to reduce the risk of eczema (follow-up period until 24 months of age) when taken in the last trimester of pregnancy (RR $0.71 ; 95 \% \mathrm{Cl}, 0.60-0.84$ ), when taken by breast-feeding mothers (RR 0.57; $95 \% \mathrm{Cl}, 0.47-0.69$ ), or when given to infants and/or mothers (RR, 0.80; 95\% Cl, 0.68-0.94). However, no significant effect on eczema development was observed when probiotics were administered only to infants (RR, $0.83 ; 95 \% \mathrm{Cl}, 0.58-1.19)$. Consistent with the metaanalysis of Zuccotti et al, [44] no benefit on any other allergic manifestation was reported. The certainty in the evidence when evaluated by the Grading of Recommendation Assessment Development and Evaluation (GRADE) approach was found to be low or very low due to "risk of bias, inconsistency and imprecision of results, and indirectness of available research" [16]. Although the evidence for a combined perinatal intervention appears stronger, it is still open to question when in the gestation period the intervention should be initiated, and for how long it should continue in the postnatal period [17].

\section{Atopy, food allergy and respiratory allergic disease}

In a recent meta-analysis of 17 trials (2947 infants) [45], pooled analysis indicated that a combined pre- and postnatal probiotic treatment reduced the risk of (any) sensitization (RR $0.78 ; 95 \% \mathrm{Cl} 0.66-0.92$ ), especially when administered prenatally to the pregnant mother and postnatally to the infant (RR $0.71 ; 95 \% \mathrm{Cl} 0.57-0.89$ ); and also the risk of food sensitization (RR $0.77 ; 95 \% \mathrm{Cl} 0.61-0.98$ ). Prenatal or postnatal probiotic administration

This article is protected by copyright. All rights reserved. 
alone did not influence the risk of sensitization. The authors concluded that there is still need for studies assessing the effects of probiotics for prevention of food allergy using objective evaluations, i.e. food challenges [45]. This was also identified by the Prevention Taskforce for the European Academy of Allergy and Clinical Immunology's (EAACI) Guidelines for Food Allergy and Anaphylaxis that concluded that the current available evidence does not support the use of probiotics for food allergy prevention [46]. Similarly, for respiratory allergies, the evidence remains low. In a meta-analysis of 9 trials (3257 children) the RR of diagnosed asthma in children randomized to receive probiotics was 0.99 (95\% Cl $0.81-1.21)$ and the RR of incident wheeze was $0.97(95 \% \mathrm{Cl}$ 0.87- 1.09), based on 9 trials (1949 children) [47]. Collectively, the current available evidence does not support a role for probiotics for prevention of other allergic manifestations than eczema. The evidence does not exclude such as possibility either, however $[16,17]$, as the majority of studies has not been adequately powered to examine the effects of less prevalent allergic manifestations (e.g. asthma and food allergy). To summarize, more RCTs are needed to examine the role of probiotics for primary prevention of atopy, food allergy and respiratory allergies.

\section{Primary prevention studies using prebiotics}

Prebiotics have been defined as "a selectively fermented ingredient that allows specific changes, both in the composition and/or activity in the gastrointestinal microbiota, thus conferring benefit(s) upon host health" [48]. Human milk is plentiful of human milk oligosaccharides that serve as substrates for specific microbes and shape infant gut microbiota establishment [49]. Consequently, galactooligosaccharides and/or fructooligosaccharides have been added to infant formula to try to mimic the effects of HMOs when breastfeeding is not feasible. In the most recent systematic review of prebiotics for allergy prevention [48], meta-analysis of five studies (1313 infants) found no significant difference in eczema (RR: 0.57, $95 \% \mathrm{Cl}$ : 0.30-1.08); whereas meta-analysis of the two studies (249 infants) that reported early respiratory outcomes found a reduction in infant asthma or recurrent wheeze (RR: $0.37,95 \% \mathrm{Cl}$ : 0.17-0.80) in prebiotic-treated infants. One single study assessed the risk of developing food allergy and reported a reduction (R: 0.28 , $95 \% \mathrm{Cl}$ 0.08-1.00) by prebiotics [50].

The first RCT to examine the effects of prebiotics for allergy prevention included nonexclusively breastfed infants at high risk of allergic disease (based on parental family history) [51]. Infants were assigned to an extensively hydrolysed formula with (or without) prebiotics $(90 \%$ short-chain galactooligosaccharides (scGOS) and $10 \%$ long-chain fructooligosaccharides (ICFOS)), which approximates to the proportions of these 
oligosaccharides in human milk. Partial breastfeeding was allowed until 6 weeks of age. There was a significant decrease in the cumulative incidence of eczema at six months of age in the prebiotic compared with the placebo group (9.8\% versus $23.1 \%$ ) [51] and the benefit was sustained at two and five years of age $[52,53]$, although limited by a high dropout rate at the latter ages. Ivakhnenko et al [54], also found reduced cumulative incidence of eczema at 18 months of age in an open RCT of non-breastfed children fed standard formula with scGOS/lcFOS compared with standard formula without any addition. In a double-blind RCT including children at low risk of atopy (based on the absence of allergic heredity), there was a transient benefit of prebiotics (nonhydrolyzed cow's milk-based formula with scGOS and ICFOS and long-chain fructo-OS, ratio 9:1, plus specific pectin-derived acidic oligosaccharides) on eczema in the first year of life [55], but this was not sustained at preschool age [56]. The authors concluded that although prebiotics transiently prevented early eczema in this non-breastfed low atopy risk population, the number needed to treat to prevent 1 case of eczema was 25 infants. Thus, recommendations need to weigh the cost, effort and burden of these interventions against transient benefits [56]. Collectively, more carefully conducted RCTs in both high and low atopy risk populations are needed before firm conclusions on the effectiveness of prebiotics for allergy prevention in formula-fed infants can be drawn.

\section{Primary prevention studies using synbiotics}

Although less studied, synbiotics (a combination of prebiotics and probiotics) have also been examined for the prevention of eczema $[25,57]$. In a recent meta-analysis of synbiotics [58], the pooled relative risk ratio $(\mathrm{RR})$ of eczema for synbiotic treatment versus placebo was 0.44 (95\% Cl, 0.11-1.83) (2 studies, 1320 children). This meta-analysis included the Kukkonen 'synbiotic' study [25] (Table 1) that has also been included in most meta-analyses of 'probiotics' for primary prevention of allergic diseases. The review concluded that there is still need for studies to assess the effects of synbiotics for primary prevention of eczema [58] and obviously, this includes the need to assess the effect on other allergic outcomes as well.

\section{Challenges when evaluating and comparing pre- and probiotics for allergy prevention}

As identified in many reviews and opinion papers, the lack of harmonisation of probiotic primary prevention studies hampers direct comparison. It also remains to be determined which preventive strategy is most effective, including the optimal strains, dosages, timing and duration. As discussed by Cuello-Garcia et al [16], there is still call for well-designed and executed RCTs to examine the effects of probiotics in the prevention of all allergic diseases,

This article is protected by copyright. All rights reserved. 
as well as potential adverse effects, to reduce the overall risk of bias. Compared with primary prevention studies using probiotics, there are still relatively few published studies using prebiotics specifically for allergy prevention, although the nutritional benefit of prebiotics has been examined in other studies. Still, lack of harmonisation is apparent in existing prebiotic studies as well. Collectively, there is a call for uniform clinical outcome assessments and harmonisation of protocols in future prebiotic and probiotic studies.

\section{Recent recommendations regarding probiotics and prebiotics for eczema prevention}

International expert bodies including EAACI, the American Academy of Pediatrics, European Society for Paediatric Gastroenterology Hepatology and Nutrition (ESPGHAN), National Institute of Allergy and Infectious Diseases (NIAID) and Food and Agriculture Organization of the United Nations/World Health Organization (FAO/WHO) [46, 59-62] do not generally recommend probiotics for allergy prevention at this time. However, recent GRADE based guidelines from the World Allergy Organization (WAO) concluded that, when taking into account all the critical outcomes, there is a likely net advantage of probiotics, resulting primarily from eczema prevention [50]. However, there was a lack of evidence that probiotics prevented any other allergic conditions. As discussed, these findings are consistent with recent meta-analyses [16, 44, 45, 47]. In otherwise healthy individuals, the WAO guideline panel suggested considering using probiotics in pregnant women, during breastfeeding, and in infancy if the child is at high risk of developing allergic disease - where this risk is defined by family history of allergic disease in a first-degree relative. In their report, the WAO guideline panel also stressed that the recommendations are conditional, and based on very low quality evidence due to the great heterogeneity between studies [50]. The heterogeneity between studies also makes it difficult to translate these recommendations into practical advice regarding specific strains, optimal dosages and treatment timing and duration [50]. Choice of strains, treatment duration and timing can have different effects on vertical transmission, immune modulation and gut microbiota composition, as discussed in more detail below, thus critically influencing the preventive outcome.

Even more recently, the WAO guideline panel suggested using prebiotic supplementation in not-exclusively breastfed infants for allergy prevention and not using prebiotic supplementation in exclusively breastfed infants, also based on GRADE evidence decision frameworks [48]. Again, the panel stressed that the recommendations are conditional and based on very low certainty of the evidence.

This article is protected by copyright. All rights reserved. 


\section{Microbial transmission from mother to offspring and possible varying capacity for vertical transmission between probiotic strains}

The importance of a combined prenatal and postnatal supplementation for the preventive effect of probiotics on infant eczema suggests that the maternal microbial environment during pregnancy is involved in shaping childhood immune maturation [1, 17, 63-65]. In support of this, maternal exposure to a traditional farm environment during pregnancy confers stronger protection against allergic sensitisation and disease than postnatal exposure alone [66]. The mechanisms by which prenatal exposures influence immune developmental trajectories need to be clarified, but are the likely result of the close immunological interaction between mother and foetus during pregnancy [17, 63-65, 67]. Recently, direct presentation of maternal bacterial components to the foetus has been recognised as a potential route for immune imprinting $[17,65,67,68]$, which may in some way prepare for the much larger inoculum transferred during vaginal delivery [10,69-74] and breastfeeding $[69,73,75,76]$.

This adds to the increasing evidence that the first interactions between the microbiota and the host are initiated in utero, contrary to assumptions of a "sterile womb" paradigm in which the first acquisition of bacteria occurs at birth $[69,77,78]$. Any microbial presence in utero has been assumed to be dangerous for the foetus, based on intrauterine infections as a risk factor for preterm birth [79]. However, intracellular bacteria have been histologically demonstrated at a similar rate in the basal plate (the peripheral region of the placenta on the maternal side in contact with the uterine wall) in preterm and term pregnancies without overt infection [79]. Furthermore, bacterial DNA has been detected in placenta [78, 80, 81], amniotic fluid [78, 81], umbilical cord [82] and meconium [78, 83, 84] after 'sterile' term elective caesarean section deliveries. Finally, a low abundance but metabolically rich placental microbiome was identified in normal healthy pregnancies at term by extensive deep sequencing [77]. Importantly, data obtained by 16S rRNA gene sequencing only demonstrates the presence of microbial DNA, without direct evidence of viable bacteria. Nonetheless, the presence of microbial DNA in the intrauterine compartment suggests that the fetus may be in direct contact with microbial components during gestation [65]. Similarities between the placental and oral microbiome composition [77] have led to speculation that the placental microbiome is partially established by haematogenous spread of oral microbiota [65, 77]. Microbiota sampling and characterization from the same pregnant women at multiple sites would give important information to address this further.

This article is protected by copyright. All rights reserved. 
Another hypothesis is that maternal bacteria may reach the placenta via the bloodstream after dendritic cell facilitated translocation over the gut epithelium [65, 69]. An experimental mouse study using labelled Enterococcus faecium demonstrated transfer of maternal bacteria to foetuses in utero via the gastrointestinal tract [82], and enhanced translocation of gut bacteria to mesenteric lymph nodes has been demonstrated during pregnancy and lactation [65, 85]. In support of an entero-mammary-pathway, maternal intestinal microbes have been detected in immune cells circulating in peripheral blood and in breast milk in both lactating mice and humans [85]. Furthermore, the probiotic bacterium Lactobacillus reuteri could be detected in colostrum after administration from gestational week 36 to delivery in mothers participating in an allergy intervention study [75]. It would be highly interesting to investigate whether probiotic bacterial components may be transferred from the mother to her foetus in utero after maternal supplementation in future human intervention studies.

Vertical transmission of maternal vaginal and gut microbes to the neonate occurs during vaginal delivery [10, 69-74]. Caesarean section (CS) delivery, which is performed with increasing rates worldwide and may increase the risk for development of allergy and other immune mediated diseases [1], thus disrupts the opportunities for the microbiota to be transferred from a mother to her baby [10, 69-74]. Vaginally delivered infants, but not infants born by CS, share a significantly higher proportion of gut microbiota 16S rRNA gene sequences with their own mother than with other mothers during the first year of life [71, 72]. The importance of maternal gut derived bacteria in early infant gut colonization is also supported by the findings of a recent one month-follow up study, where CS delivered neonates were inoculated with maternal vaginal microbes [86]. Thus, the gut microbiota of the infants was not influenced by the "vaginal seeding" to the same extent as their skin and oral microbiota, as maternal gut derived bacteria, which are specialized to thrive in this niche, expanded in the stool samples of vaginally delivered but not inoculated CS delivered neonates [86].

It needs to be established how probiotics are transferred from mother to offspring when the mother is supplemented during pregnancy and lactation [87]. A recent study suggested that the capacity for vertical transmission may vary between different probiotic strains. Mothers were supplemented with a mixture of three probiotic strains; Lactobacillus rhamnosus GG, Bifidobacterium animalis subsp lactis $\mathrm{Bb}-12$ and Lactobacillus acidophilus La-5 from 36 weeks gestation and during breastfeeding for three months [88]. Only Lactobacillus rhamnosus GG and not the other probiotic strains were detected in infant stool samples during the first three months of life, however [88]. The influence of mode of delivery would have been interesting to address, but this information was unfortunately not available.

This article is protected by copyright. All rights reserved. 
Further studies on the complex interactions between the maternal and offspring microbiome and immunity are needed to identify strategies to avert the allergy epidemic.

\section{What are the immune modulating effects of probiotics?}

\section{Breast milk composition may be affected by probiotics}

Probiotics may affect the composition of breast milk since nutritional, metabolic and immunological processes in the gut could be reflected in the mammary gland and milk via the entero-mammary pathway [69]. In addition to providing nutrients for growth and development, breast milk also contains many important immunological components. In several probiotic intervention studies, the influence of supplementation on the immune profile of breast milk has been investigated (Supplementary Table 1). In 3 month samples transforming growth factor- $\beta 2$ (TGF$\beta 2$ ) was increased in breast milk from mothers receiving $L$. rhamnosus $G G$ compared with placebo [89]. Another study found that colostrum TGF- $\beta 2$ levels were higher in individuals treated with $L$. rhamnosus $G G$ and $B$. lactis $\mathrm{Bb}$ than with placebo but no other mediators measured were affected by supplementation [28]. In contrast, TGF- $\beta 2$ levels in colostrum were decreased after supplementation with $L$. reuteri compared with placebo and also associated with less likelihood to become sensitized during their first two years in life [90]. The same study found increased levels of interleukin-10 (IL-10) in colostrum of probiotic treated mothers [90]. Increased IL-10 levels and reduced levels of immunoglobulin A $(\lg A)$ to casein were observed in 3 month milk samples after supplementation with a mix of $L$. rhamnosus GG and LC705 and B. breve Bb99 and Proprionibacterium freudenreichii ssp. shermani JS plus prebiotic galactooligosaccharides in another cohort, while total IgA levels and IgA levels to cow milk (CM), beta-lactoglobulin (BLG) and ovalbumin (OVA) in colostrum were similar [91]. In this study, human neutrophil alpha-defensins (HNP1-3), human $\beta$-defensin 2 (HBD2) or SCD14 levels were not affected by the synbiotic treatment [92]. In contrast, another study found lower milk levels of SCD14 at day 7 and total $\lg A$ at day 28 in L. rhamnosus GG compared with placebo treated participants, while TGF- $\beta 1$ levels were not affected by the intervention [19]. However, colostrum TGF- $\beta 1$ levels were increased after $B$. lactis supplementation in another study, with a similar tendency after L. rhamnosus supplementation [93]. 
Increased colostrum IgA levels were observed after both $B$. lactis and $L$. rhamnosus administration [93]. In conclusion, supplementation has not consistently affected breast milk TGF- $\beta 1$, TGF- $\beta 2$ and IgA levels and immunomodulatory effects likely vary between strains.

\section{Probiotic supplementation may induce some peripheral tolerance}

Several theories have been proposed regarding the effect of probiotic supplementation on peripheral immune responses, including enhanced immune maturation, increased T helper 1 (Th1) associated immunity, but also induction of T regulatory cells (Tregs) and increased tolerance. Studies have collected both cord and peripheral blood mononuclear cells and by various measures tried to elucidate the effect of supplementation on peripheral immunity (Supplementary Table 1). However, prenatal $L$. rhamnosus GG supplementation did not influence dendritic cell (DC) and Treg phenotype and numbers [94]. In the same cohort, no differences in cytokine production after stimulation of CBMC with Toll Like receptor (TLR) ligands were observed [19]. Another study investigated the effect of L. rhamnosus GG stimulation on cord blood mononuclear cells (CBMC) and found that stimulation resulted in enhanced release of IL-10 and interferon-y (IFN- $\mathrm{\gamma}$ ) but independently of probiotic supplementation [95]. After pre- and postnatal L. reuteri supplementation, reduced allergen responsiveness was observed during the first two years of life in the probiotic compared with the placebo group, i.e. reduced cat allergen induced levels of IL- 5 and IL-13 at 6 months, IFN-y at 24 months, IL-10 at birth and 12 months [96]. Furthermore, probiotic supplementation was associated with reduced CCL22 levels after birch stimulation at 24 months [96]. Also, in the same cohort, probiotic supplementation was associated with reduced Lipoteichoic acid (LTA) induced C-C Motif Chemokine Ligand (CCL4), C-X-C Motif Chemokine Ligand (CXCL8), IL-1 $\beta$ and IL-6 levels [97]. Reduced anti-CD2/CD28 induced IL-5 and IL-13 levels in whole blood cultures was noted at 3 months of age after pre- and postnatal supplementation with a mixture of $B$. bifidum, $B$. lactis and $L$. lactis as compared with placebo [29]. The same pattern with reduced responses to polyclonal stimuli with Staphylococcal Enterotoxin B (SEB) (lower IL-5 and TGF- $\beta$ levels) and house dust mite (HDM) allergens (lower tumour necrosis factor (TNF) and IL-10) at 6 months 
were found after postnatal $L$. acidophilus as compared with placebo administration [98], while responses to TLR2 and TLR4 [99] and Treg frequencies were not affected by the intervention [100]. Feeding $L$. paracasei ssp paracasei $F 19$ during weaning was associated with a higher ratio of anti-CD3/CD28 induced IFN-y/LL-4 [34] and IFN-Y/IL-2 mRNA [101] at 13 months of age.

Collectively, probiotic supplementation during pregnancy and/or infancy may be associated with reduced cytokine responses to certain stimuli. All studies have slightly different designs and time points for sample collection, however, in addition to the variation in probiotic strains and treatment duration.

\section{Immune deviation in vivo as measured by circulating immunoglobulin, cytokine and chemokine levels}

Circulating chemokine and cytokine levels may reflect immune deviation in vivo. Probiotic supplementation has shown minor effects on these mediators (Supplementary Table 1). In an intervention trial using two strains, L. rhamnosus but not B. lactis supplementation was associated with increased cord blood IFN- $\gamma$ levels as compared with placebo [93]. Pre- and postnatal synbiotic administration led to elevated C-reactive protein (CRP), total IgA, total IgE and IL-10 levels at 6 months [102], suggestive of a low-grade inflammation. Total IgE levels at 13 months were not affected by feeding L. paracasei ssp paracasei F19 during weaning, however [34]. In another intervention study, detection of $L$. reuteri in faeces, collected during the first week, was associated with lower levels of the Th2-associated chemokines CCL22 and CCL17 and higher Th1-associated CXCL11 levels at 6 months, while the levels were not significantly different in the probiotic vs placebo group [103].

To summarise, consistent effects on infant immune deviation in vivo by probiotic supplementation have not yet been observed, possibly due to strain specific effects. 


\section{Effects on antibody titres to vaccines}

As the immunomodulatory mechanisms behind probiotic supplementation are still unclear, effects on immune responsiveness to vaccines in probiotic supplemented infants can provide further clues and are also of importance from a safety point of view. Supplementation postnatally with $L$. rhamnosus LPR and $B$. longum was found to enhance Hepatitis B (HepB) surface antibody responses at 12 months in subjects receiving monovalent doses of HepB vaccine at birth, 1 month and a DTPa-HepB combination vaccine at 6 months, but not those who received 3 monovalent doses [104]. Supplementation with L. paracasei ssp paracasei F19 (LF19) during weaning increased the capacity to mount responses to vaccine protein antigens, but not a polysaccharide antigen [105]. More specifically, antibody concentrations to Haemophilus influenzae type b (Hib) capsular polysaccharide (HibPS), diphtheria toxin (D) and tetanus toxoid (T) before and after the second and third doses were measured. LF19 enhanced antibody concentrations to D and T, especially in infants breastfed less than 6 months. Conversely, breastfeeding duration influenced the anti-HibPS concentrations, with no effect by LF19 [105]. In another intervention study using a mix of L. rhamnosus GG and LC705 and B. breve Bb99 and Proprionibacterium freudenreichii ssp. shermani JS plus prebiotic galactooligosaccharides, infants were immunized with a DTwP (diphtheria, tetanus and whole cell pertussis) and with a Hib polysaccharide. In the probiotic group, protective Hib antibody concentrations occurred more frequently at 6 months, while diphtheria and tetanus, $\lg$ titers were comparable in the different groups [106]. Thus, while there is some evidence that probiotic supplementation may enhance antibody responses to certain vaccine antigens, the specific effects seem to vary between strains.

\section{Epigenetic modulation after probiotic interventions}

Epigenetic modifications can alter the DNA sequence without heritable changes and have been shown to be important in perinatal immune programming. The effects of pre- and postnatal probiotic supplementation may thus be mediated by epigenetic mechanisms [17]. No published studies so far have investigated the effect of probiotic supplementation on epigenetic regulation in infants, and it would be interesting to see studies reporting the epigenetic effects of intervention.

This article is protected by copyright. All rights reserved. 


\section{Genetic influences on clinical outcomes}

Genetic predisposition may affect the outcome of intervention trials, since eczema prevalence for example are different in various regions were studies have been conducted [107]. One study found that 26 TLR Single nucleotide polymorphisms (SNPs) interacted with $L$. rhamnosus resulting in a reduced risk of eczema, while only two interacted with $B$. lactis resulting in a reduced risk of eczema, eczema severity or atopy [108]. Another study from the same cohort found that infants carrying an eczema susceptibility genetic variant (among 33 eczema susceptibility SNPs in eleven genes) were less likely to develop eczema if they had been randomised to the $L$. rhamnosus group compared to placebo. B. lactis were also capable to protect against the effect of some SNPs [109]. Genetic effects on clinical outcomes have not been reported in other intervention studies.

\section{Safety reports}

There have been discussions about the safety of using live bacteria in intervention trials including pregnant and lactating mothers as well as neonates and infants. No severe adverse events have been reported in allergy prevention trials, although on rare occasions sepsis has been observed in high-risk immunocompromised patients [110]. Intake of lactobacilli and bifidobacteria during pregnancy had no effect on the incidence of caesarean section, birth weight, or gestational age in a pooled analysis of several different studies [111]. In addition, several studies have evaluated the effect of supplementation on height and weight development in children, after follow up for 4 to 8 years [36-38, 40,112, 113]. Administration of $L$. reuteri [37], $L$. paracasei ssp paracasei $F 19$ [112], L. rhamnosus GG [114] a combination with $L$. rhamnosus HN001 or B. lactis HN019 [38], L. rhamnosus LGG and B. longum BL999 [40], synbiotic mix of $L$. rhamnosus $G G$ and LC705, B. breve Bb99 and Proprionibacterium freudenreichii ssp. Shermani JS plus prebiotic galactooligosaccharides [36] had no effects on these measures. Haemoglobin values decreased during administration of the synbiotic mix but at age 2 the hematologic values in both groups were equal [115]. In summary, probiotic supplementation during pregnancy and infancy may be considered safe. 


\section{The effect of probiotics on gut microbiota composition}

Probiotic supplementation has been hypothesised to have a beneficial effect on the gut microbiota. However, when comparing the results from different studies it is important to acknowledge how varying methodologies may affect the findings. Traditional culture based methods are hard to compare with the next generation sequencing tools that are available today. There is some evidence for a bifidogenic effect of probiotic supplementation [116, 117], although this has not been consistently observed [29, 32]. Also, the probiotic strain has been detected in faeces during but not after the administration period in several studies (Supplementary Table 1).

The effect of prenatal $L$. rhamnosus GG supplementation on infant gut microbiota development was evaluated by quantitative Polymerase Chain Reaction (qPCR) for Bifidobacterium quantity [116] and Terminal Restriction Fragment Length Polymorphism (T-RFLP) for Bifidobacterium [116] or overall species composition [118]. At one week, diversity was not promoted by $L$. rhamnosus GG supplementation [118], and at 90 days of age infants of supplemented mothers were more often colonised with B. longum [116]. Furthermore, pre- and postnatal supplementation with $L$. rhamnosus GG enhanced the early bifidobacterial diversity in infants in another cohort [117]. Higher counts of bifidobacteria were found at 2 years of age after supplementation with $L$. reuteri compared with placebo to the mother from gestational week 36 to delivery and to the child during the first 12 months [75], while no effects on gut microbiota diversity was detected by next generation sequencing [8]. L. reuteri was found in the majority of supplemented infants stool, with the highest recording at 5-6 days of age [75]. Increased faecal counts of all supplemented bacteria were observed when feeding infants a mix of $L$. rhamnosus GG and LC705, B. breve Bb99 and Proprionibacterium freudenreichii ssp. Shermani JS plus prebiotic galactosaccharides for 6 months, while no differences between groups were observed at 2 years of age [25]. In another study investigating the effect of maternal supplementation with $L$. rhamnosus $G G, B$. animalis subsp. lactis $\mathrm{Bb}-12$ and $L$. acidophilus La-5 from 36 weeks gestation and during breastfeeding for three months, L. rhamnosus GG was detected more frequently by qPCR in infant stool samples in the supplemented group than the placebo group at 10 days and 3 months but not at 1 and 2 years, while the other 
strains were not detected more frequently in the probiotic than the supplemented group at any time point [88]. Gut microbiota diversity was not affected by the intervention, as analysed by next generation sequencing [88]. It may be possible that certain strains of probiotics are more efficient colonisers than other supplemented strains also after direct administration to the infant. One study comparing $L$. rhamnosus $\mathrm{HN001}$ and $B$. lactis HN019 supplementation found that $L$. rhamnosus was more likely than $B$. lactis to be present in stool samples at 3 months, although detection rates were similar at 24 months, at the end of the supplementation period [27]. In addition, in another study L. lactis and B. bifidum but not $B$. lactis were detectable more often in the probiotic group (L. lactis, B. lactis and B. bifidum) compared with placebo at 3 months of age [29]. Infants supplemented with $L$. acidophilus were more often colonised with lactobacilli at 6 months but no other significant differences were observed [32].

Long term follow up of gut microbiota development has been performed so far in one study [119] up to the age of six years, where only minor and short term differences were observed between the probiotic and placebo groups using 16S-23S rDNA interspace region based profiling. Children were reported to have a gut microbiota development determined by age rather than intervention and atopic status.

In conclusion, while the probiotic strain may be transiently detected during the supplementation period in most studies, clear gut microbial diversity promoting effects early in life have not been observed. Long-term effects remain to be investigated, as few such studies have been performed. The effects on gut microbiota composition seem to depend on choice of strain and treatment duration, which is consistent with the reported strain-specific differences also for immunomodulatory and clinical outcomes.

\section{How may the WAO recommendations be received and handled by clinicians and parents?}

When giving advice in medical care it is important to have a discussion about the ethics in giving recommendations. When is it ethical to give advice and recommendations? The enormous amount of information that parents are required to 
handle and process when attending the medical care during pregnancy is also an important consideration. As previously mentioned, WAO has given conditional guidelines for probiotic use [50], concluding that there is a net benefit from using probiotics in pregnancy, lactation and in infancy resulting from the prevention of eczema when there is considered to be a high-risk of allergy. There was a lack of evidence that probiotics prevented any other allergy, however. According to the document conditional recommendations mean that the majority of patients may want the suggested course of action, but others may not. Clinicians are required to guide families in making decisions consistent with their values and preferences. Good scientific support is required in when translating general recommendations to 'specific' practical guidance, and this is still lacking (regarding exactly which strains to use, when exactly to start these and when to cease them). The balance is that variations in these parameters are unlikely to cause harm, if families choose to use these products. Families should also be made aware that the protective effects are limited and so far only apply to eczema.

\section{What is needed to address these uncertainties - for more specific recommendations to consumers}

The fact that the WAO recommendations are supported by low quality evidence by the GRADE guidelines [50] does not mean that the studies are necessarily of low quality, but rather that they are very heterogeneous in design. This contributes to the difficulty in translating WAO recommendations to specifics regarding choice of strains, dose, timing, mode of administration and duration. Further research is warranted to determine the differential effects of these factors on immune modulation and gut microbiota composition. One way to address this is a well-coordinated multicentre collaborative effort, which could include harmonised studies focused on different aspects of this issue but collectively with sufficient power to look at both long term outcomes and assess the differential effects in different risk groups (i.e. such as caesarean delivery), in different genetic backgrounds and in environmental contexts where the risk of disease may also be different. Similar designs of these harmonised studies regarding strains, dose, timing, mode of administration and duration are important. We contend that most previous studies have focused on only 
late pregnancy - largely with the focus of achieving vertical transmission of the microbiota, rather than on the direct immunomodulatory effects of optimising the maternal microbiome in utero. Together with prebiotics, probiotics (studied separately and/or together) is an important avenue of investigation. Importantly, probiotics are regarded as safe during pregnancy [111], and even in premature neonates where they have become standard practice in many centres to reduce the risk of necrotizing enterocolitis [120]. Thus, supplementing women earlier in pregnancy is both feasible and reasonable and should be an important element of multicentre efforts. While this is an ideal scenario, cross-continental/jurisdictional studies face many challenges - including substantive funding and regulatory challenges. If researchers work together in consortia these challenges will become more surmountable.

\section{Conclusion}

Meta-analyses show a benefit of probiotics for prevention of eczema but not other allergic symptoms, and the WAO guidelines suggest using probiotics in pregnant and lactating women and in infants when there is high risk of allergy in the children. Further research is required to be able to translate the WAO recommendations into practice guidelines, however, as specific advice on choice of strains, dose, timing, mode of administration and duration is not possible to give due to the great heterogeneity between studies performed so far $[1,17,121,122]$. Replication of the promising results in collaborative well-coordinated multicentre harmonised studies with multidisciplinary expertise in paediatrics, immunology and microbiology would thus be of great importance to enable future evidence-based implementation.

This article is protected by copyright. All rights reserved. 


\begin{tabular}{|c|c|c|c|c|}
\hline Study population and probiotic intervention & Effect on eczema & Effect on sensitization & $\begin{array}{l}\text { Effect on } \\
\text { respiratory } \\
\text { symptoms }\end{array}$ & Effect on lung function measures \\
\hline \multicolumn{5}{|l|}{ MATERNAL ADMINISTRATION ONLY } \\
\hline $\begin{array}{l}\text { Huurre et al, } 2008 \text { [28] } \\
\text { Maternal allergic disease } \\
\text { L. rhamnosus GG and B. lactis Bb-12 } 1 \times 10^{10} \mathrm{CFU} \text { daily from first } \\
\text { trimester and then to breastfeeding mother until cessation of } \\
\text { exclusive breastfeeding }\end{array}$ & $\begin{array}{l}\text { No } \\
\text { Long term outcomes not } \\
\text { reported }\end{array}$ & Not reported & $\begin{array}{l}\text { Not } \\
\text { reported }\end{array}$ & Not reported \\
\hline $\begin{array}{l}\text { Dotterud et al, } 2010 \text { [20] and Simpson et al, } 2015 \text { [43] } \\
\text { Unselected - about 2/3 with family history of allergic disease } \\
\text { L. rhamnosus GG, L. acidophilus LA5, and B. lactis Bb-12 ( } 5 \mathrm{x} \\
10^{10} \mathrm{CFU} \text { of each daily) from } 36 \text { weeks gestation and then to } \\
\text { breastfeeding mother for } 3 \text { months }\end{array}$ & $\begin{array}{l}\text { Reduced cumulative } \\
\text { incidence of eczema at } 2 \\
\text { and } 6 \text { years }\end{array}$ & No & No & Not reported \\
\hline $\begin{array}{l}\text { Boyle et al, } 2011[19] \\
\text { Any first degree relative with allergic disease } \\
\text { L. rhamnosus GG } 1.8 \times 10^{10} \mathrm{CFU} \text { daily from } 36 \text { weeks gestation } \\
\text { until delivery - no postnatal administration to mother }\end{array}$ & $\begin{array}{l}\text { No at } 12 \text { months } \\
\text { Long term } \\
\text { outcomes not } \\
\text { reported }\end{array}$ & No & No & Not reported \\
\hline
\end{tabular}

This article is protected by copyright. All rights reserved. 


\begin{tabular}{|c|c|c|c|c|}
\hline $\begin{array}{l}\text { Rautava et al, } 2012[21] \\
\text { Maternal allergic disease } \\
\text { L. rhamnosus LPR and B. longum BL999 or L. paracasei and } B \text {. } \\
\text { longum BL9 - each probiotic at a daily dose of } 1 \times 10^{9} \mathrm{CFU} \text { from } \\
\text { two months before delivery and during two months to } \\
\text { breastfeeding mother }\end{array}$ & $\begin{array}{l}\text { Reduction of eczema at } 2 \\
\text { years in both probiotic } \\
\text { groups } \\
\text { Long term } \\
\text { outcomes not } \\
\text { reported }\end{array}$ & No & $\begin{array}{l}\text { Not } \\
\text { reported }\end{array}$ & Not reported \\
\hline \multicolumn{5}{|l|}{ PERINATAL ADMINISTRATION TO MOTHER AND/OR CHILD } \\
\hline $\begin{array}{l}\text { Kalliomäki et al, } 2001 \text { [23] and Kalliomäki et al, } 2007 \text { [35] } \\
\text { Any first degree relative with allergic disease } \\
\text { L. rhamnosus GG } 1 \times 10^{10} \mathrm{CFU} \text { daily given to mothers } 2-4 \text { weeks } \\
\text { before delivery and then to breastfeeding mothers or directly to } \\
\text { infant, for } 6 \text { months }\end{array}$ & $\begin{array}{l}\text { Reduction of eczema at } 2 \\
\text { years which remained at } 7 \\
\text { years }\end{array}$ & No & No & No \\
\hline $\begin{array}{l}\text { Abrahamsson et al, } 2007 \text { [26] and Abrahamsson et al, } 2013 \\
\text { [37] } \\
\text { Any first degree relative with allergic disease } \\
\text { L. reuteri } 1 \times 10^{8} \mathrm{CFU} \text { daily } 2-4 \text { weeks before delivery and then } \\
\text { to infant for } 12 \text { months }\end{array}$ & $\begin{array}{l}\text { No reduction of eczema, } \\
\text { but reduction of IgE- } \\
\text { associated eczema in the } \\
\text { probiotic group at } 2 \text { years } \\
\text { No difference between the } \\
\text { two groups at } 7 \text { years } \\
\text { follow up }\end{array}$ & No & No & $\begin{array}{l}\text { No differences between the } \\
\text { groups when evaluated by } \\
\text { spirometry reversibility test } \\
\text { and FeNO levels at } 7 \text { years }\end{array}$ \\
\hline $\begin{array}{l}\text { Kukkonen et al, } 2007 \text { [25] and Kuitunen et al, } 2009 \text { [36] } \\
\text { Any first degree relative with allergic disease }\end{array}$ & $\begin{array}{l}\text { Eczema reduction in the } \\
\text { probiotic group at } 2 \text { years }\end{array}$ & No & No & $\begin{array}{l}\text { No differences in FeNO levels } \\
\text { between the groups at } 5 \\
\text { years in a randomized }\end{array}$ \\
\hline
\end{tabular}

This article is protected by copyright. All rights reserved. 


\begin{tabular}{|c|c|c|c|c|}
\hline $\begin{array}{l}\text { Mix of L. rhamnosus GG and LC705 (both } 5 \times 10^{9} \text { ) and B. breve } \\
\text { Bb99 and Proprionibacterium freudenreichii ssp. shermani JS } \\
\text { (both } 2 \times 10^{9} \text { ) plus prebiotic galactooligosaccharides; given twice } \\
\text { daily to mother } 2-4 \text { weeks before delivery and then to infant for } 6 \\
\text { months }\end{array}$ & $\begin{array}{l}\text { No eczema reduction at } \\
\text { five years }\end{array}$ & & & subpopulation \\
\hline $\begin{array}{l}\text { Kopp et al, } 2008 \text { [24] } \\
\text { Any first degree relative with allergic disease } \\
\text { L. rhamnosus GG } 1 \times 10^{10} \text { CFU daily given to mothers } 4-6 \text { weeks } \\
\text { before delivery and then to breastfeeding mother for } 3 \text { months or } \\
\text { to infant for } 6 \text { months }\end{array}$ & $\begin{array}{l}\text { No at } 2 \text { years } \\
\text { Long term outcomes not } \\
\text { reported }\end{array}$ & No & No & Not reported \\
\hline $\begin{array}{l}\text { Wickens et al, } 2008 \text { [27] and Wickens et al, } 2013 \text { [38] } \\
\text { Any first degree relative with allergic disease } \\
\text { L. rhamnosus HN001 or B. lactis HN019 } 1 \times 10^{10} \mathrm{CFU} \text { daily from } \\
2-5 \text { weeks before delivery and then to infant directly for } 2 \text { years }\end{array}$ & $\begin{array}{l}\text { Eczema reduction in the } L \text {. } \\
\text { rhamnosus group at } 2 \\
\text { years which remained until } \\
6 \text { years } \\
\text { No benefit of } B \text {. lactis }\end{array}$ & $\begin{array}{l}\text { Lower cumulative } \\
\text { sensitisation in the group } \\
\text { receiving } L \text {. rhamnosus } \\
\text { at } 6 \text { years } \\
\text { No benefit of } B \text {. lactis }\end{array}$ & No & $\begin{array}{l}\text { No differences between the } \\
\text { groups when evaluated by } \\
\text { spirometry reversibility test } \\
\text { and FeNO levels at } 6 \text { years }\end{array}$ \\
\hline $\begin{array}{l}\text { Niers et al, } 2009 \text { [29] and } \\
\text { Gorissen et al, 2014 [42] } \\
\text { Allergic disease of either parent and in at least one sibling } \\
\text { Lactococcus lactis W58, B. lactis W52 and B. bifidum W23 } 1 \text { x } \\
10^{9} \text { CFU each daily six weeks before delivery and then directly } \\
\text { to infant for } 12 \text { months }\end{array}$ & $\begin{array}{l}\text { Reduced cumulative } \\
\text { incidence of eczema in the } \\
\text { first three months of life } \\
\text { No difference at } 6 \text { years }\end{array}$ & No & No & Not reported \\
\hline $\begin{array}{l}\text { Kim et al, } 2010 \text { [30] } \\
\text { Any first degree relative with allergic disease }\end{array}$ & $\begin{array}{l}\text { Reduced cumulative } \\
\text { incidence and prevalence }\end{array}$ & Not reported & $\begin{array}{l}\text { Not } \\
\text { reported }\end{array}$ & Not reported \\
\hline
\end{tabular}

This article is protected by copyright. All rights reserved. 


\begin{tabular}{|c|c|c|c|c|}
\hline $\begin{array}{l}\text { B. bifidum BGN4, B. lactis AD011, and L. acidophilus AD031(1.6 } \\
\times 10^{\circ} \mathrm{CFU} \text { of each daily) } 4-8 \text { weeks before delivery, } 3 \text { months to } \\
\text { breastfeeding mother and then to infant from } 4 \text { to } 6 \text { months }\end{array}$ & $\begin{array}{l}\text { of eczema at } 12 \text { months } \\
\text { Long term outcomes not } \\
\text { reported }\end{array}$ & & & \\
\hline $\begin{array}{l}\text { Ou et al, } 2012 \text { [22] } \\
\text { Maternal allergic disease } \\
\text { L. rhamnosus GG } 1 \times 10^{10} \mathrm{CFU} \text { daily from second trimester and } \\
\text { then } 6 \text { months to mother if breastfeeding or directly to infant }\end{array}$ & $\begin{array}{l}\text { No } \\
\text { Long term } \\
\text { outcomes not } \\
\text { reported }\end{array}$ & No & No & Not reported \\
\hline $\begin{array}{l}\text { Allen et al, } 2014 \text { [31] } \\
\text { Any first degree relative with allergic disease } \\
\text { L. salivaris CUL61, L. paracasei CUL08, B. animalis ssp lactis } \\
\text { CUL34 and B. bifidum CUL20, } 10^{10} \mathrm{CFU} \text { daily in total starting 2- } \\
4 \text { weeks before delivery and then to the infant for six months }\end{array}$ & $\begin{array}{l}\text { No reduction of eczema, } \\
\text { but a reduction of lgE- } \\
\text { associated eczema at } 2 \\
\text { years of age in the } \\
\text { probiotic group }\end{array}$ & Not reported & No & Not reported \\
\hline \multicolumn{5}{|l|}{ POSTNATAL ADMINISTRATION } \\
\hline $\begin{array}{l}\text { Taylor et al, } 2007 \text { [32] and } \\
\text { Jensen et al, } 2012[39] \\
\text { Maternal allergic disease } \\
\text { L. acidophilus (LAVRI-A1) } 3 \times 10^{8} \mathrm{CFU} \text { given within } 48 \text { hours, } \\
\text { and then for six months, directly to infant }\end{array}$ & $\begin{array}{l}\text { No reduction at } 1 \text { year nor } \\
\text { at the or } 5 \text { year follow-up }\end{array}$ & $\begin{array}{l}\text { No } \\
\text { Sensitisation more } \\
\text { common in the probiotic } \\
\text { group at } 1 \text { year, but not } \\
\text { at the later follow-ups }\end{array}$ & No & Not reported \\
\hline
\end{tabular}

This article is protected by copyright. All rights reserved. 


\begin{tabular}{|c|c|c|c|c|}
\hline $\begin{array}{l}\text { Soh et al, } 2009 \text { [33] and } \\
\text { Loo et al, } 2014 \text { [40] } \\
\text { Any first degree relative with allergic disease, L. rhamnous LPR } \\
1 \times 10^{9} \mathrm{CFU} \text { and B. longum (BL999) } 6 \times 10^{8} \mathrm{CFU} \text { daily to infant } \\
\text { (in infant formula) for } 6 \text { months }\end{array}$ & $\begin{array}{l}\text { No reduction at } 2 \text { or } 5 \\
\text { years }\end{array}$ & No & No & Not reported \\
\hline $\begin{array}{l}\text { West et al, } 2009 \text { [34] } \\
\text { West et al, } 2013 \text { [41] } \\
\text { Mixed (2/3 with at least one first grade relative with allergic } \\
\text { disease) } \\
\text { L. paracasei ssp paracasei } \mathrm{F} 191 \times 10^{9} \mathrm{CFU} \text { daily to infant (in } \\
\text { infant cereal) during weaning from } 4-13 \text { months }\end{array}$ & $\begin{array}{l}\text { Reduced cumulative } \\
\text { incidence of eczema at } 13 \\
\text { months } \\
\text { No difference at } 8 \text { years }\end{array}$ & No & No & $\begin{array}{l}\text { No differences between the } \\
\text { groups when evaluated by } \\
\text { spirometry reversibility test } \\
\text { and FeNO levels at } 8 \text { years }\end{array}$ \\
\hline
\end{tabular}

The table was modified from West CE, Probiotics for allergy prevention, Beneficial Microbes 2016; 7: 171-9

This article is protected by copyright. All rights reserved. 


\section{References}

1. West CE, Jenmalm MC, Prescott SL, The gut microbiota and its role in the development of allergic disease: a wider perspective. Clin Exp Allergy 2014; 45: 43-53.

2. Wesemann DR, Nagler CR, The Microbiome, Timing, and Barrier Function in the Context of Allergic Disease. Immunity 2016; 44: 728-38.

3. Björkstén B, Sepp E, Julge $K$, Voor T, Mikelsaar $M$, Allergy development and the intestinal microflora during the first year of life. J Allergy Clin Immunol 2001; 108: 516-20.

4. Kalliomäki M, Kirjavainen P, Eerola E, Kero P, Salminen S, Isolauri E, Distinct patterns of neonatal gut microflora in infants in whom atopy was and was not developing. J Allergy Clin Immunol 2001; 107: 129-34.

5. Penders J, Thijs C, van den Brandt PA, Kummeling I, Snijders B, Stelma F, Adams H, van Ree $R$, Stobberingh EE, Gut microbiota composition and development of atopic manifestations in infancy: the KOALA Birth Cohort Study. Gut 2007; 56: 661-7.

6. Sjögren YM, Jenmalm MC, Böttcher MF, Björkstén B, Sverremark-Ekström E, Altered early infant gut microbiota in children developing allergy up to 5 years of age. Clin Exp Allergy 2009; 39: 518-26.

7. Bisgaard H, Li N, Bonnelykke K, Chawes BL, Skov T, Paludan-Muller G, Stokholm J, Smith B, Krogfelt KA, Reduced diversity of the intestinal microbiota during infancy is associated with increased risk of allergic disease at school age. J Allergy Clin Immunol 2011; 128: 646-52 e15.

8. Abrahamsson TR, Jakobsson HE, Andersson AF, Björkstén B, Engstrand L, Jenmalm MC, Low diversity of the gut microbiota in infants with atopic eczema. J Allergy Clin Immunol 2012; 129: 434-40, 40 e1-2.

9. Ismail IH, Oppedisano F, Joseph SJ, Boyle RJ, Licciardi PV, Robins-Browne RM, Tang ML, Reduced gut microbial diversity in early life is associated with later development of eczema but not atopy in high-risk infants. Pediatr Allergy Immunol 2012; 23: 674-81.

10. Penders J, Gerhold K, Stobberingh EE, Thijs C, Zimmermann K, Lau S, Hamelmann E, Establishment of the intestinal microbiota and its role for atopic dermatitis in early childhood. J Allergy Clin Immunol 2013; 132: 601-07 e8.

11. Azad MB, Konya T, Guttman DS, Field CJ, Sears MR, HayGlass KT, Mandhane PJ, Turvey SE, Subbarao P, Becker AB, Scott JA, Kozyrskyj AL, Infant gut microbiota and food sensitization: associations in the first year of life. Clin Exp Allergy 2015; 45: 632-43.

12. Abrahamsson TR, Jakobsson HE, Andersson AF, Bjorksten B, Engstrand L, Jenmalm MC, Low gut microbiota diversity in early infancy precedes asthma at school age. Clin Exp Allergy 2014; 44: 842-50.

This article is protected by copyright. All rights reserved. 
13. West CE, Ryden P, Lundin D, Engstrand L, Tulic MK, Prescott SL, Gut microbiome and innate immune response patterns in IgE-associated eczema. Clin Exp Allergy 2015; 45: 1419-29.

14. Arrieta MC, Stiemsma LT, Dimitriu PA, Thorson L, Russell S, Yurist-Doutsch S, Kuzeljevic B, Gold MJ, Britton HM, Lefebvre DL, Subbarao P, Mandhane P, Becker A, McNagny KM, Sears MR, Kollmann T, Mohn WW, Turvey SE, Finlay BB, Early infancy microbial and metabolic alterations affect risk of childhood asthma. Sci Transl Med 2015; 7: 307ra152.

15. Osborn DA, Sinn JK, Prebiotics in infants for prevention of allergy. Cochrane Database Syst Rev 2013; 3: CD006474.

16. Cuello-Garcia CA, Brozek JL, Fiocchi A, Pawankar R, Yepes-Nunez JJ, Terracciano L, Gandhi S, Agarwal A, Zhang $Y$, Schunemann HJ, Probiotics for the prevention of allergy: A systematic review and meta-analysis of randomized controlled trials. J Allergy Clin Immunol 2015; 136: 952-61.

17. West CE, Jenmalm MC, Kozyrskyj AL, Prescott SL, Probiotics for treatment and primary prevention of allergic diseases and asthma: looking back and moving forward. Exp Rev Clin Immunol 2016: 1-15.

18. FAO/WHO, Health and nutritional properties of probiotics in food including powder milk with live lactic acid bacteria. Report of a joint FAO/WHO expert consultation on evaluation of health and nutritional properties in food including powder milk with live lactic acid bacteria., 2001.

19. Boyle RJ, Ismail IH, Kivivuori S, Licciardi PV, Robins-Browne RM, Mah LJ, Axelrad C, Moore S, Donath S, Carlin JB, Lahtinen SJ, Tang ML, Lactobacillus GG treatment during pregnancy for the prevention of eczema: a randomized controlled trial. Allergy 2011; 66: 509-16.

20. Dotterud CK, Storro O, Johnsen R, Oien T, Probiotics in pregnant women to prevent allergic disease: a randomized, double-blind trial. Br J Dermatol 2010; 163: 616-23.

21. Rautava S, Kainonen E, Salminen S, Isolauri E, Maternal probiotic supplementation during pregnancy and breast-feeding reduces the risk of eczema in the infant. J Allergy Clin Immunol 2012; 130: 1355-60.

22. Ou CY, Kuo HC, Wang L, Hsu TY, Chuang H, Liu CA, Chang JC, Yu HR, Yang KD, Prenatal and postnatal probiotics reduces maternal but not childhood allergic diseases: a randomized, double-blind, placebo-controlled trial. Clin Exp Allergy 2012; 42: 1386-96.

23. Kalliomäki $M$, Salminen $S$, Arvilommi $H$, Kero $P$, Koskinen $P$, Isolauri $E$, Probiotics in primary prevention of atopic disease: a randomised placebo-controlled trial. Lancet 2001; 357: 107679.

24. Kopp MV, Hennemuth I, Heinzmann A, Urbanek R, Randomized, double-blind, placebocontrolled trial of probiotics for primary prevention: no clinical effects of Lactobacillus GG supplementation. Pediatrics 2008; 121: e850-6.

This article is protected by copyright. All rights reserved. 
25. Kukkonen K, Savilahti E, Haahtela T, Juntunen-Backman K, Korpela R, Poussa T, Tuure T, Kuitunen $\mathrm{M}$, Probiotics and prebiotic galacto-oligosaccharides in the prevention of allergic diseases: a randomized, double-blind, placebo-controlled trial. J Allergy Clin Immunol 2007; 119: 192-8.

26. Abrahamsson TR, Jakobsson $T$, Bottcher MF, Fredrikson $M$, Jenmalm MC, Bjorksten $B$, Oldaeus $\mathrm{G}$, Probiotics in prevention of IgE-associated eczema: a double-blind, randomized, placebo-controlled trial. J Allergy Clin Immunol 2007; 119: 1174-80.

27. Wickens K, Black PN, Stanley TV, Mitchell E, Fitzharris P, Tannock GW, Purdie G, Crane J, A differential effect of 2 probiotics in the prevention of eczema and atopy: a double-blind, randomized, placebo-controlled trial. J Allergy Clin Immunol 2008; 122: 788-94.

28. Huurre A, Laitinen K, Rautava S, Korkeamaki M, Isolauri E, Impact of maternal atopy and probiotic supplementation during pregnancy on infant sensitization: a double-blind placebocontrolled study. Clin Exp Allergy 2008; 38: 1342-8.

29. Niers L, Martin R, Rijkers G, Sengers F, Timmerman H, van Uden N, Smidt H, Kimpen J, Hoekstra $M$, The effects of selected probiotic strains on the development of eczema (the PandA study). Allergy 2009; 64: 1349-58.

30. Kim JY, Kwon JH, Ahn SH, Lee SI, Han YS, Choi YO, Lee SY, Ahn KM, Ji GE, Effect of probiotic mix (Bifidobacterium bifidum, Bifidobacterium lactis, Lactobacillus acidophilus) in the primary prevention of eczema: a double-blind, randomized, placebo-controlled trial. Pediatr Allergy Immunol 2010; 21: e386-93.

31. Allen SJ, Jordan S, Storey M, Thornton CA, Gravenor MB, Garaiova I, Plummer SF, Wang D, Morgan G, Probiotics in the prevention of eczema: a randomised controlled trial. Arch Dis Child 2014; 99: 1014-9.

32. Taylor AL, Dunstan JA, Prescott SL, Probiotic supplementation for the first 6 months of life fails to reduce the risk of atopic dermatitis and increases the risk of allergen sensitization in high-risk children: a randomized controlled trial. J Allergy Clin Immunol 2007; 119: 184-91.

33. Soh SE, Aw M, Gerez I, Chong YS, Rauff M, Ng YP, Wong HB, Pai N, Lee BW, Shek LP, Probiotic supplementation in the first 6 months of life in at risk Asian infants--effects on eczema and atopic sensitization at the age of 1 year. Clin Exp Allergy 2009; 39: 571-8.

34. West $\mathrm{CE}$, Hammarström ML, Hernell $\mathrm{O}$, Probiotics during weaning reduce the incidence of eczema. Pediatr Allergy Immunol 2009; 20: 430-7.

35. Kalliomäki M, Salminen S, Poussa T, Isolauri E, Probiotics during the first 7 years of life: a cumulative risk reduction of eczema in a randomized, placebo-controlled trial. J Allergy Clin Immunol 2007; 119: 1019-21.

36. Kuitunen M, Kukkonen K, Juntunen-Backman K, Korpela R, Poussa T, Tuure T, Haahtela T, Savilahti E, Probiotics prevent IgE-associated allergy until age 5 years in cesarean-delivered children but not in the total cohort. J Allergy Clin Immunol 2009; 123: 335-41.

This article is protected by copyright. All rights reserved. 
37. Abrahamsson TR, Jakobsson T, Bjorksten B, Oldaeus G, Jenmalm MC, No effect of probiotics on respiratory allergies: a seven-year follow-up of a randomized controlled trial in infancy. Pediatr Allergy Immunol 2013; 24: 556-61.

38. Wickens K, Stanley TV, Mitchell EA, Barthow C, Fitzharris P, Purdie G, Siebers R, Black PN, Crane J, Early supplementation with Lactobacillus rhamnosus HNOO1 reduces eczema prevalence to 6 years: does it also reduce atopic sensitization? Clin Exp Allergy 2013; 43: 1048-57.

39. Jensen MP, Meldrum S, Taylor AL, Dunstan JA, Prescott SL, Early probiotic supplementation for allergy prevention: long-term outcomes. J Allergy Clin Immunol 2012; 130: 1209-11 e5.

40. Loo EX, Llanora GV, Lu Q, Aw MM, Lee BW, Shek LP, Supplementation with probiotics in the first 6 months of life did not protect against eczema and allergy in at-risk Asian infants: a 5year follow-up. Int Arch Allergy Immunol 2014; 163: 25-8.

41. West CE, Hammarstrom ML, Hernell O, Probiotics in primary prevention of allergic disease-follow-up at 8-9 years of age. Allergy 2013; 68: 1015-20.

42. Gorissen DM, Rutten NB, Oostermeijer CM, Niers LE, Hoekstra MO, Rijkers GT, van der Ent $\mathrm{CK}$, Preventive effects of selected probiotic strains on the development of asthma and allergic rhinitis in childhood. The Panda study. Clin Exp Allergy 2014; 44: 1431-3.

43. Simpson MR, Dotterud CK, Storro O, Johnsen R, Oien T, Perinatal probiotic supplementation in the prevention of allergy related disease: 6 year follow up of a randomised controlled trial. BMC Dermatol 2015; 15: 13.

44. Zuccotti G, Meneghin F, Aceti A, Barone G, Callegari ML, Di Mauro A, Fantini MP, Gori D, Indrio F, Maggio L, Morelli L, Corvaglia L, Probiotics for prevention of atopic diseases in infants: systematic review and meta-analysis. Allergy 2015; 70: 1356-71.

45. Zhang GQ, Hu HJ, Liu CY, Zhang Q, Shakya S, Li ZY, Probiotics for Prevention of Atopy and Food Hypersensitivity in Early Childhood: A PRISMA-Compliant Systematic Review and MetaAnalysis of Randomized Controlled Trials. Medicine (Baltimore) 2016; 95: e2562.

46. Muraro A, Halken S, Arshad SH, Beyer K, Dubois AE, Du Toit G, Eigenmann PA, Grimshaw KE, Hoest A, Lack G, O'Mahony L, Papadopoulos NG, Panesar S, Prescott S, Roberts G, de Silva D, Venter C, Verhasselt V, Akdis AC, Sheikh A, EAACl food allergy and anaphylaxis guidelines. Primary prevention of food allergy. Allergy 2014; 69: 590-601.

47. Azad MB, Coneys JG, Kozyrskyj AL, Field CJ, Ramsey CD, Becker AB, Friesen C, Abou-Setta $A M$, Zarychanski R, Probiotic supplementation during pregnancy or infancy for the prevention of asthma and wheeze: systematic review and meta-analysis. Bmj 2013; 347: f6471.

48. Cuello-Garcia CA, Fiocchi A, Pawankar R, Yepes-Nunez JJ, Morgano GP, Zhang Y, Ahn K, AlHammadi S, Agarwal A, Gandhi S, Beyer K, Burks W, Canonica GW, Ebisawa M, Kamenwa R, Lee BW, Li H, Prescott S, Riva JJ, Rosenwasser L, Sampson H, Spigler M, Terracciano L, Vereda A, Waserman S, Schunemann HJ, Brozek JL, World Allergy Organization-McMaster University

This article is protected by copyright. All rights reserved. 
Guidelines for Allergic Disease Prevention (GLAD-P): Prebiotics. World Allergy Organ J 2016; 9: 10.

49. Bode L, The functional biology of human milk oligosaccharides. Early Hum Dev 2015; 91: 619-22.

50. Fiocchi A, Pawankar R, Cuello-Garcia C, Ahn K, Al-Hammadi S, Agarwal A, Beyer K, Burks W, Canonica GW, Ebisawa M, Gandhi S, Kamenwa R, Lee BW, Li H, Prescott S, Riva JJ, Rosenwasser L, Sampson H, Spigler M, Terracciano L, Vereda-Ortiz A, Waserman S, YepesNunez JJ, Brozek JL, Schunemann HJ, World Allergy Organization-McMaster University Guidelines for Allergic Disease Prevention (GLAD-P): Probiotics. World Allergy Organ J 2015; 8: 4.

51. Moro G, Arslanoglu S, Stahl B, Jelinek J, Wahn U, Boehm G, A mixture of prebiotic oligosaccharides reduces the incidence of atopic dermatitis during the first six months of age. Arch Dis Child 2006; 91: 814-9.

52. Arslanoglu S, Moro GE, Boehm G, Wienz F, Stahl B, Bertino E, Early neutral prebiotic oligosaccharide supplementation reduces the incidence of some allergic manifestations in the first 5 years of life. J Biol Regul Homeost Agents 2012; 26: 49-59.

53. Arslanoglu S, Moro GE, Schmitt J, Tandoi L, Rizzardi S, Boehm G, Early dietary intervention with a mixture of prebiotic oligosaccharides reduces the incidence of allergic manifestations and infections during the first two years of life. J Nutr 2008; 138: 1091-5.

54. Ivakhnenko OS, Nyankovskyy SL, Effect of the specific infant formula mixture of oligosaccharides on local immunity and development of allergic and infectious disease in young children: Randomized study. Pediatr Pol 2013; 88: 398-404.

55. Gruber C, van Stuijvenberg M, Mosca F, Moro G, Chirico G, Braegger CP, Riedler J, Boehm G, Wahn $U$, Reduced occurrence of early atopic dermatitis because of immunoactive prebiotics among low-atopy-risk infants. J Allergy Clin Immunol 2010; 126: 791-7.

56. Gruber C, van Stuivenberg M, Mosca F, Moro G, Chirico G, Braegger CP, Riedler J, Yavuz Y, Boehm G, Wahn U, Immunoactive prebiotics transiently prevent occurrence of early atopic dermatitis among low-atopy-risk infants. J Allergy Clin Immunol 2015; 136: 1696-8 e1.

57. Roze JC, Barbarot S, Butel MJ, Kapel N, Waligora-Dupriet AJ, De Montgolfier I, Leblanc M, Godon N, Soulaines P, Darmaun D, Rivero M, Dupont C, An alpha-lactalbumin-enriched and symbiotic-supplemented v. a standard infant formula: a multicentre, double-blind, randomised trial. Br J Nutr 2012; 107: 1616-22.

58. Chang YS, Trivedi MK, Jha A, Lin YF, Dimaano L, Garcia-Romero MT, Synbiotics for Prevention and Treatment of Atopic Dermatitis: A Meta-analysis of Randomized Clinical Trials. JAMA Pediatr 2016; 170: 236-42.

59. Thomas DW, Greer FR, American Academy of Pediatrics Committee on N, American Academy of Pediatrics Section on Gastroenterology H, Nutrition, Probiotics and prebiotics in pediatrics. Pediatrics 2010; 126: 1217-31.

This article is protected by copyright. All rights reserved. 
60. Braegger C, Chmielewska A, Decsi T, Kolacek S, Mihatsch W, Moreno L, Piescik M, Puntis J, Shamir R, Szajewska H, Turck D, van Goudoever J, Nutrition ECo, Supplementation of infant formula with probiotics and/or prebiotics: a systematic review and comment by the ESPGHAN committee on nutrition. J Pediatr Gastroenterol Nutr 2011; 52: 238-50.

61. Morelli L, Capurso L, FAO/WHO guidelines on probiotics: 10 years later. J Clin Gastroenterol 2012; 46 Suppl: S1-2.

62. Panel NI-SE, Boyce JA, Assa'ad A, Burks AW, Jones SM, Sampson HA, Wood RA, Plaut M, Cooper SF, Fenton MJ, Arshad SH, Bahna SL, Beck LA, Byrd-Bredbenner C, Camargo CA, Jr., Eichenfield L, Furuta GT, Hanifin JM, Jones $C$, Kraft M, Levy BD, Lieberman P, Luccioli S, McCall KM, Schneider LC, Simon RA, Simons FE, Teach SJ, Yawn BP, Schwaninger JM, Guidelines for the diagnosis and management of food allergy in the United States: report of the NIAID-sponsored expert panel. J Allergy Clin Immunol 2010; 126: S1-58.

63. Jenmalm MC, Childhood immune maturation and allergy development: regulation by maternal immunity and microbial exposure. Am J Reprod Immunol 2011; 66 Suppl 1: 75-80.

64. Jenmalm MC, Duchen K, Timing of allergy-preventive and immunomodulatory dietary interventions - are prenatal, perinatal or postnatal strategies optimal? Clin Exp Allergy 2013; 43: 273-8.

65. Abrahamsson TR, Wu RY, Jenmalm MC, Gut microbiota and allergy: the importance of the pregnancy period. Pediatr Res 2014; 77: 214-9.

66. von Mutius $E$, The microbial environment and its influence on asthma prevention in early life. J Allergy Clin Immunol 2016; 137: 680-9.

67. Gollwitzer ES, Marsland BJ, Impact of Early-Life Exposures on Immune Maturation and Susceptibility to Disease. Trends Immunol 2015; 36: 684-96.

68. Gomez de Aguero M, Ganal-Vonarburg SC, Fuhrer T, Rupp S, Uchimura Y, Li H, Steinert A, Heikenwalder M, Hapfelmeier S, Sauer U, McCoy KD, Macpherson AJ, The maternal microbiota drives early postnatal innate immune development. Science 2016; 351: 1296302.

69. Funkhouser LJ, Bordenstein SR, Mom knows best: the universality of maternal microbial transmission. PLoS Biol 2013; 11: e1001631.

70. van Nimwegen FA, Penders J, Stobberingh EE, Postma DS, Koppelman GH, Kerkhof M, Reijmerink NE, Dompeling E, van den Brandt PA, Ferreira I, Mommers M, Thijs C, Mode and place of delivery, gastrointestinal microbiota, and their influence on asthma and atopy. The Journal of allergy and clinical immunology 2011; 128: 948-55 e1-3.

71. Jakobsson HE, Abrahamsson TR, Jenmalm MC, Harris K, Quince C, Jernberg C, Bjorksten B, Engstrand L, Andersson AF, Decreased gut microbiota diversity, delayed Bacteroidetes colonisation and reduced Th1 responses in infants delivered by caesarean section. Gut 2014; 63: 559-66.

This article is protected by copyright. All rights reserved. 
72. Bäckhed F, Roswall J, Peng Y, Feng Q, Jia H, Kovatcheva-Datchary P, Li Y, Xia Y, Xie H, Zhong H, Khan MT, Zhang J, Li J, Xiao L, Al-Aama J, Zhang D, Lee YS, Kotowska D, Colding C, Tremaroli V, Yin Y, Bergman S, Xu X, Madsen L, Kristiansen K, Dahlgren J, Wang J, Dynamics and Stabilization of the Human Gut Microbiome during the First Year of Life. Cell Host Microbe 2015; 17: 852.

73. Azad MB, Konya T, Persaud RR, Guttman DS, Chari RS, Field CJ, Sears MR, Mandhane PJ, Turvey SE, Subbarao P, Becker AB, Scott JA, Kozyrskyj AL, Impact of maternal intrapartum antibiotics, method of birth and breastfeeding on gut microbiota during the first year of life: a prospective cohort study. Bjog 2016; 123: 983-93.

74. Dogra S, Sakwinska O, Soh SE, Ngom-Bru C, Bruck WM, Berger B, Brussow H, Lee YS, Yap F, Chong YS, Godfrey KM, Holbrook JD, Dynamics of infant gut microbiota are influenced by delivery mode and gestational duration and are associated with subsequent adiposity. MBio 2015; 6 .

75. Abrahamsson TR, Sinkiewicz G, Jakobsson T, Fredrikson M, Bjorksten B, Probiotic lactobacilli in breast milk and infant stool in relation to oral intake during the first year of life. J Pediatr Gastroenterol Nutr 2009; 49: 349-54.

76. Mastromarino P, Capobianco D, Miccheli A, Pratico G, Campagna G, Laforgia N, Capursi T, Baldassarre ME, Administration of a multistrain probiotic product (VSL\#3) to women in the perinatal period differentially affects breast milk beneficial microbiota in relation to mode of delivery. Pharmacol Res 2015; 95-96: 63-70.

77. Aagaard K, Ma J, Antony KM, Ganu R, Petrosino J, Versalovic J, The placenta harbors a unique microbiome. Sci Transl Med 2014; 6: 237 ra65.

78. Collado MC, Rautava S, Aakko J, Isolauri E, Salminen S, Human gut colonisation may be initiated in utero by distinct microbial communities in the placenta and amniotic fluid. Sci Rep 2016; 6: 23129.

79. Stout MJ, Conlon B, Landeau M, Lee I, Bower C, Zhao Q, Roehl KA, Nelson DM, Macones GA, Mysorekar IU, Identification of intracellular bacteria in the basal plate of the human placenta in term and preterm gestations. Am J Obstet Gynecol 2013; 208: 226 e1-7.

80. Satokari R, Gronroos T, Laitinen K, Salminen S, Isolauri E, Bifidobacterium and Lactobacillus DNA in the human placenta. Lett Appl Microbiol 2009; 48: 8-12.

81. Rautava S, Collado MC, Salminen S, Isolauri E, Probiotics modulate host-microbe interaction in the placenta and fetal gut: a randomized, double-blind, placebo-controlled trial. Neonatology 2012; 102: 178-84.

82. Jimenez E, Fernandez L, Marin ML, Martin R, Odriozola JM, Nueno-Palop C, Narbad A, Olivares $\mathrm{M}$, Xaus J, Rodriguez JM, Isolation of commensal bacteria from umbilical cord blood of healthy neonates born by cesarean section. Curr Microbiol 2005; 51: 270-4.

83. Jimenez E, Marin ML, Martin R, Odriozola JM, Olivares M, Xaus J, Fernandez L, Rodriguez JM, Is meconium from healthy newborns actually sterile? Res Microbiol 2008; 159: 187-93.

This article is protected by copyright. All rights reserved. 
84. Gosalbes MJ, Llop S, Valles Y, Moya A, Ballester F, Francino MP, Meconium microbiota types dominated by lactic acid or enteric bacteria are differentially associated with maternal eczema and respiratory problems in infants. Clin Exp Allergy 2013; 43: 198-211.

85. Perez PF, Dore J, Leclerc M, Levenez F, Benyacoub J, Serrant P, Segura-Roggero I, Schiffrin EJ, Donnet-Hughes $A$, Bacterial imprinting of the neonatal immune system: lessons from maternal cells? Pediatrics 2007; 119: e724-32.

86. Dominguez-Bello MG, De Jesus-Laboy KM, Shen N, Cox LM, Amir A, Gonzalez A, Bokulich NA, Song SJ, Hoashi M, Rivera-Vinas JI, Mendez K, Knight R, Clemente JC, Partial restoration of the microbiota of cesarean-born infants via vaginal microbial transfer. Nat Med 2016; 22: 250-3.

87. West CE, Jenmalm MC, Transfer of Probiotic Bacteria From Mother to Child: A Matter of Strain Specificity? J Pediatr Gastroenterol Nutr 2015; 61: 157-8.

88. Dotterud CK, Avershina E, Sekelja M, Simpson MR, Rudi K, Storro O, Johnsen R, Oien T, Does Maternal Perinatal Probiotic Supplementation Alter the Intestinal Microbiota of Mother and Child? J Pediatr Gastroenterol Nutr 2015; 61: 200-7.

89. Rautava S, Kalliomaki M, Isolauri E, Probiotics during pregnancy and breast-feeding might confer immunomodulatory protection against atopic disease in the infant. J Allergy Clin Immunol 2002; 109: 119-21.

90. Böttcher MF, Abrahamsson TR, Fredriksson M, Jakobsson T, Bjorksten B, Low breast milk TGF-beta2 is induced by Lactobacillus reuteri supplementation and associates with reduced risk of sensitization during infancy. Pediatr Allergy Immunol 2008; 19: 497-504.

91. Kuitunen M, Kukkonen AK, Savilahti E, Impact of maternal allergy and use of probiotics during pregnancy on breast milk cytokines and food antibodies and development of allergy in children until 5 years. Int Arch Allergy Immunol 2012; 159: 162-70.

92. Savilahti EM, Kukkonen AK, Kuitunen M, Savilahti E, Soluble CD14, alpha-and beta-defensins in breast milk: association with the emergence of allergy in a high-risk population. Innate Immun 2015; 21: 332-7.

93. Prescott SL, Wickens K, Westcott L, Jung W, Currie H, Black PN, Stanley TV, Mitchell EA, Fitzharris $P$, Siebers R, Wu L, Crane J, Supplementation with Lactobacillus rhamnosus or Bifidobacterium lactis probiotics in pregnancy increases cord blood interferon-gamma and breast milk transforming growth factor-beta and immunoglobin A detection. Clin Exp Allergy 2008; 38: 1606-14.

94. Boyle RJ, Mah L, Chen A, Kivivuori S, Robins-Browne RM, Tang ML, Effects of Lactobacillus $G G$ treatment during pregnancy on the development of fetal antigen-specific immune responses. Clin Exp Allergy 2008; 38: 1882-90.

95. Kopp MV, Goldstein M, Dietschek A, Sofke J, Heinzmann A, Urbanek R, Lactobacillus GG has in vitro effects on enhanced interleukin-10 and interferon-gamma release of mononuclear

This article is protected by copyright. All rights reserved. 
cells but no in vivo effects in supplemented mothers and their neonates. Clin Exp Allergy 2008; 38: 602-10.

96. Forsberg A, Abrahamsson TR, Björkstén B, Jenmalm MC, Pre- and post-natal Lactobacillus reuteri supplementation decreases allergen responsiveness in infancy. Clin Exp Allergy 2013; 43: 434-42.

97. Forsberg A, Abrahamsson TR, Bjorksten B, Jenmalm MC, Pre- and postnatal administration of Lactobacillus reuteri decreases TLR2 responses in infants. Clin Transl Allergy 2014; 4: 21.

98. Taylor AL, Hale J, Wiltschut J, Lehmann H, Dunstan JA, Prescott SL, Effects of probiotic supplementation for the first 6 months of life on allergen- and vaccine-specific immune responses. Clin Exp Allergy 2006; 36: 1227-35.

99. Taylor A, Hale J, Wiltschut J, Lehmann H, Dunstan JA, Prescott SL, Evaluation of the effects of probiotic supplementation from the neonatal period on innate immune development in infancy. Clin Exp Allergy 2006; 36: 1218-26.

100. Taylor AL, Hale J, Hales BJ, Dunstan JA, Thomas WR, Prescott SL, FOXP3 mRNA expression at 6 months of age is higher in infants who develop atopic dermatitis, but is not affected by giving probiotics from birth. Pediatr Allergy Immunol 2007; 18: 10-9.

101. West CE, Hernell O, Andersson Y, Sjöstedt M, Hammarström ML, Probiotic effects on T-cell maturation in infants during weaning. Clin Exp Allergy 2012; 42: 540-9.

102. Marschan E, Kuitunen M, Kukkonen K, Poussa T, Sarnesto A, Haahtela T, Korpela R, Savilahti $E$, Vaarala $O$, Probiotics in infancy induce protective immune profiles that are characteristic for chronic low-grade inflammation. Clin Exp Allergy 2008; 38: 611-18.

103. Abrahamsson TR, Sandberg Abelius M, Forsberg A, Björkstén B, Jenmalm MC, A Th1/Th2associated chemokine imbalance during infancy in children developing eczema, wheeze and sensitization. Clin Exp Allergy 2011; 41: 1729-39.

104. Soh SE, Ong DQ, Gerez I, Zhang X, Chollate P, Shek LP, Lee BW, Aw M, Effect of probiotic supplementation in the first 6 months of life on specific antibody responses to infant Hepatitis B vaccination. Vaccine 2010; 28: 2577-9.

105. West CE, Gothefors L, Granstrom M, Kayhty H, Hammarstrom ML, Hernell O, Effects of feeding probiotics during weaning on infections and antibody responses to diphtheria, tetanus and Hib vaccines. Pediatr Allergy Immunol 2008; 19: 53-60.

106. Kukkonen $\mathrm{K}$, Nieminen $\mathrm{T}$, Poussa $\mathrm{T}$, Savilahti $\mathrm{E}$, Kuitunen $\mathrm{M}$, Effect of probiotics on vaccine antibody responses in infancy--a randomized placebo-controlled double-blind trial. Pediatr Allergy Immunol 2006; 17: 416-21.

107. Flohr C, Mann J, New insights into the epidemiology of childhood atopic dermatitis. Allergy 2014; 69: 3-16.

This article is protected by copyright. All rights reserved. 
108. Marlow G, Han DY, Wickens K, Stanley T, Crane J, Mitchell EA, Dekker J, Barthow C, Fitzharris $P$, Ferguson LR, Morgan AR, Differential effects of two probiotics on the risks of eczema and atopy associated with single nucleotide polymorphisms to Toll-like receptors. Pediatr Allergy Immunol 2015; 26: 262-71.

109. Morgan AR, Han DY, Wickens K, Barthow C, Mitchell EA, Stanley TV, Dekker J, Crane J, Ferguson LR, Differential modification of genetic susceptibility to childhood eczema by two probiotics. Clin Exp Allergy 2014; 44: 1255-65.

110. Embleton ND, Zalewski S, Berrington JE, Probiotics for prevention of necrotizing enterocolitis and sepsis in preterm infants. Curr Opin Infect Dis 2016; 29: 256-61.

111. Dugoua JJ, Machado M, Zhu X, Chen X, Koren G, Einarson TR, Probiotic safety in pregnancy: a systematic review and meta-analysis of randomized controlled trials of Lactobacillus, Bifidobacterium, and Saccharomyces spp. J Obstet Gynaecol Can 2009; 31: 542-52.

112. Karlsson Videhult F, Ohlund I, Stenlund H, Hernell O, West CE, Probiotics during weaning: a follow-up study on effects on body composition and metabolic markers at school age. Eur J Nutr 2015; 54: 355-63.

113. Kukkonen K, Savilahti E, Haahtela T, Juntunen-Backman K, Korpela R, Poussa T, Tuure T, Kuitunen $\mathrm{M}$, Long-term safety and impact on infection rates of postnatal probiotic and prebiotic (synbiotic) treatment: randomized, double-blind, placebo-controlled trial. Pediatrics 2008; 122: 8-12.

114. Laitinen K, Kalliomaki M, Poussa T, Lagstrom H, Isolauri E, Evaluation of diet and growth in children with and without atopic eczema: follow-up study from birth to 4 years. Br J Nutr 2005; 94: 565-74.

115. Kuitunen M, Kukkonen K, Savilahti E, Pro- and prebiotic supplementation induces a transient reduction in hemoglobin concentration in infants. J Pediatr Gastroenterol Nutr 2009; 49: 626-30.

116. Lahtinen SJ, Boyle RJ, Kivivuori S, Oppedisano F, Smith KR, Robins-Browne R, Salminen SJ, Tang ML, Prenatal probiotic administration can influence Bifidobacterium microbiota development in infants at high risk of allergy. J Allergy Clin Immunol 2009; 123: 499-501.

117. Gueimonde M, Sakata S, Kalliomaki M, Isolauri E, Benno Y, Salminen S, Effect of maternal consumption of lactobacillus GG on transfer and establishment of fecal bifidobacterial microbiota in neonates. J Pediatr Gastroenterol Nutr 2006; 42: 166-70.

118. Ismail IH, Oppedisano F, Joseph SJ, Boyle RJ, Robins-Browne RM, Tang ML, Prenatal administration of Lactobacillus rhamnosus has no effect on the diversity of the early infant gut microbiota. Pediatr Allergy Immunol 2012; 23: 255-8.

119. Rutten NB, Gorissen DM, Eck A, Niers LE, Vlieger AM, Besseling-van der Vaart I, Budding AE, Savelkoul PH, van der Ent CK, Rijkers GT, Long Term Development of Gut Microbiota Composition in Atopic Children: Impact of Probiotics. PLoS One 2015; 10: e0137681.

This article is protected by copyright. All rights reserved. 
120. Abrahamsson TR, Not all probiotic strains prevent necrotising enterocolitis in premature infants. Lancet 2016; 387: 624-5.

121. West CE, Renz H, Jenmalm MC, Kozyrskyj AL, Allen KJ, Vuillermin P, Prescott SL, in FMIG, The gut microbiota and inflammatory noncommunicable diseases: associations and potentials for gut microbiota therapies. J Allergy Clin Immunol 2015; 135: 3-13; quiz 14.

122. West CE, Probiotics for allergy prevention. Benef Microbes 2016; 7: 171-9.

123. Savilahti EM, Kukkonen AK, Haahtela T, Tuure T, Kuitunen M, Savilahti E, Intestinal defensin secretion in infancy is associated with the emergence of sensitization and atopic dermatitis. Clin Exp Allergy 2012; 42: 405-11.

124. Kukkonen K, Kuitunen M, Haahtela T, Korpela R, Poussa T, Savilahti E, High intestinal IgA associates with reduced risk of IgE-associated allergic diseases. Pediatr Allergy Immunol 2010; 21: 67-73.

This article is protected by copyright. All rights reserved. 


\begin{tabular}{|c|c|c|c|c|c|c|}
\hline \multicolumn{7}{|l|}{ Supplementary Table 1} \\
\hline Study population and probiotic intervention & Effect on eczema & $\begin{array}{l}\text { Effect on } \\
\text { sensitization }\end{array}$ & $\begin{array}{l}\text { Effect on } \\
\text { respiratory } \\
\text { symptoms }\end{array}$ & $\begin{array}{l}\text { Effect on I } \\
\text { ung function } \\
\text { measures }\end{array}$ & Immunomodulatory effects & Effects on gut microbiota \\
\hline \multicolumn{7}{|l|}{ MATERNAL ADMINISTRATION ONLY } \\
\hline $\begin{array}{l}\text { Huurre et al, } 2008 \text { [28] } \\
\text { Maternal allergic disease } \\
\text { L. rhamnosus GG and } B \text {. lactis Bb-12 } \\
1 \times 10^{10} \mathrm{CFU} \text { daily from first trimester } \\
\text { and then to breastfeeding mother } \\
\text { until cessation of exclusive } \\
\text { breastfeeding }\end{array}$ & $\begin{array}{l}\text { No } \\
\text { Long term } \\
\text { outcomes not } \\
\text { reported }\end{array}$ & $\begin{array}{l}\text { Not } \\
\text { reported }\end{array}$ & $\begin{array}{l}\text { Not } \\
\text { reported }\end{array}$ & Not reported & $\begin{array}{l}\text { Huurre 2008; The breast milk TGF- } \beta 2 \text {, SCD14, } \\
\text { IFN- } \gamma \text {, TNF, IL-10, IL-6, IL-4 and IL-2 levels were } \\
\text { measured from samples taken immediately after } \\
\text { birth and } 1 \text { month after delivery. The colostrum } \\
\text { TGF- }-\beta 2 \text { levels tended to be higher in the } \\
\text { probiotic than the placebo group, while the other } \\
\text { mediators were not affected [28]. }\end{array}$ & Not reported \\
\hline $\begin{array}{l}\text { Dotterud et al, } 2010 \text { [20] and } \\
\text { Simpson et al, } 2015 \text { [43] } \\
\text { Unselected - about } 2 / 3 \text { with family } \\
\text { history of allergic disease } \\
\text { L. rhamnosus GG, L. acidophilus } \\
\text { LA5, and B. lactis Bb-12 ( } 5 \times 10^{10} \\
\text { CFU of each daily) from } 36 \text { weeks } \\
\text { gestation and then to breastfeeding } \\
\text { mother for } 3 \text { months }\end{array}$ & $\begin{array}{l}\text { Reduced } \\
\text { cumulative } \\
\text { incidence of } \\
\text { eczema at } 2 \\
\text { and } 6 \text { years }\end{array}$ & No & No & Not reported & Not reported & $\begin{array}{l}\text { Dotterud 2015; Infant stool samples from } \\
10 \text { days, } 3 \text { months, } 1 \text { year and } 2 \text { years, } \\
\text { were analysed by } \mathrm{qPCR} \text { and } 16 \mathrm{~S} \text { rRNA } \\
\text { gene deep sequencing on the Illumina } \\
\text { MiSeq platform. Only the LGG bacteria } \\
\text { colonized the children at } 10 \text { days and at } 3 \\
\text { months of age. There were no significant } \\
\text { differences in the abundance of the } \\
\text { probiotic bacteria between the groups at } 1 \\
\text { and } 2 \text { years of age, nor for the bacterial } \\
\text { classes and genera, alpha and beta } \\
\text { diversity [88]. }\end{array}$ \\
\hline $\begin{array}{l}\text { Boyle et al, } 2011[19] \\
\text { Any first degree relative with allergic } \\
\text { disease } \\
\text { L. rhamnosus GG } 1.8 \times 10^{10} \mathrm{CFU} \\
\text { daily from } 36 \text { weeks gestation until } \\
\text { delivery - no postnatal } \\
\text { administration to mother }\end{array}$ & $\begin{array}{l}\text { No at } 12 \\
\text { months } \\
\text { Long term } \\
\text { outcomes not } \\
\text { reported }\end{array}$ & No & No & Not reported & $\begin{array}{l}\text { Boyle 2008; CBMCs from } 73 \text { neonates were } \\
\text { cultured with heat-killed LGG, ovalbumin (OVA) } \\
\text { or without stimulus. LGG treatment of pregnant } \\
\text { women did not influence CD4+ T cell } \\
\text { proliferation, FoxP3 expression, DC phenotype } \\
\text { or cytokine secretion in CBMCS cultured with } \\
\text { heat-killed LGG or OVA [94]. } \\
\text { Boyle 2011; CBMCs from } 73 \text { neonates were } \\
\text { examined for DC and Treg numbers and LTA } \\
\text { and LPS induced production of TGF- } \beta \text {, IL-10, IL- } \\
12 p 40 \text {, IL-13, IFN- } \mathrm{L} \text { and TNF. Prenatal probiotic } \\
\text { treatment was not associated with any change in } \\
\text { cord blood immune markers or cytokine } \\
\text { secretion. Breast milk samples from the probiotic } \\
\text { group had lower levels of total IgA at day } 28 \text { and } \\
\text { lower sCD14 at day } 7 \text {, while breast milk TGF- } \beta 1 \\
\text { levels were not affected [19]. }\end{array}$ & $\begin{array}{l}\text { Lahtinen 2009; Investigated infant faecal } \\
\text { samples from } 7 \text { and } 90 \text { days using qPCR } \\
\text { and T-RFLP. At } 90 \text { days of age, infants } \\
\text { whose mothers received LGG were more } \\
\text { often colonized with species belonging to } \\
\text { the } B \text { longum group. Bifidobacterial } \\
\text { species colonization at } 7 \text { days or } \\
\text { Bifidobacterium levels did not differ } \\
\text { between the } 2 \text { groups [116]. } \\
\text { Ismail 2012; using T-RFLP analysis } \\
\text { showed that prenatal LGG failed to } \\
\text { modulate diversity of early infant gut } \\
\text { microbiota despite promoting a beneficial } \\
\text { bifidobacteria profile [118]. }\end{array}$ \\
\hline $\begin{array}{l}\text { Rautava et al, } 2012 \text { [21] } \\
\text { Maternal allergic disease }\end{array}$ & $\begin{array}{l}\text { Reduction of } \\
\text { eczema at } 2\end{array}$ & No & $\begin{array}{l}\text { Not } \\
\text { reported }\end{array}$ & Not reported & Not reported & Not reported \\
\hline
\end{tabular}




\begin{tabular}{|c|c|c|c|c|c|c|}
\hline $\begin{array}{l}\text { L. rhamnosus LPR and } B \text {. longum } \\
\text { BL999 or } L \text {. paracasei and } B \text {. longum } \\
\text { BL9 }- \text { each probiotic at a daily dose } \\
\text { of } 1 \times 10^{9} \mathrm{CFU} \text { from two months } \\
\text { before delivery and during two } \\
\text { months to breastfeeding mother }\end{array}$ & $\begin{array}{l}\text { years in both } \\
\text { probiotic } \\
\text { groups } \\
\text { Long term } \\
\text { outcomes not } \\
\text { reported }\end{array}$ & & & & & \\
\hline \multicolumn{7}{|c|}{ PERINATAL ADMINISTRATION TO MOTHER AND/OR CHILD } \\
\hline $\begin{array}{l}\text { Kalliomäki et al, } 2001[23] \text { and } \\
\text { Kalliomäki et al, } 2007[35] \\
\text { Any first degree relative with allergic } \\
\text { disease } \\
\text { L. rhamnosus } G G 1 \times 10^{10} \mathrm{CFU} \text { daily } \\
\text { given to mothers } 2-4 \text { weeks before } \\
\text { delivery and then to breastfeeding } \\
\text { mothers or directly to infant, for } 6 \\
\text { months }\end{array}$ & $\begin{array}{l}\text { Reduction of } \\
\text { eczema at } 2 \\
\text { years which } \\
\text { remained at } 7 \\
\text { years }\end{array}$ & No & No & No & $\begin{array}{l}\text { Rautava 2002; Probiotic administration } \\
\text { increased the amount of anti-inflammatory TGF- } \\
\beta 2 \text { in the milk at three months in mothers } \\
\text { receiving probiotics as analysed by ELISA. } \\
\text { Infants with elevated IgE in cord blood benefited } \\
\text { most of the probiotic supplementation [89]. }\end{array}$ & $\begin{array}{l}\text { Guiemonde 2006; At } 5 \text { days of age, } \\
\text { infants whose mothers received } L \text {. } \\
\text { rhamnosus GG showed a significantly } \\
\text { higher occurrence of } B \text {. breve and lower of } \\
B \text {. adolescentis than those from the } \\
\text { placebo group, as determined by PCR. In } \\
\text { addition, } L \text {. rhamnosus } G G \text { consumption } \\
\text { increased the bifidobacterial diversity at } 3 \\
\text { weeks in infants [117]. }\end{array}$ \\
\hline $\begin{array}{l}\text { Abrahamsson et al, } 2007 \text { [26] and } \\
\text { Abrahamsson et al, } 2013 \text { [37] } \\
\text { Any first degree relative with allergic } \\
\text { disease } \\
\text { L. reuteri } 1 \times 10^{8} \text { CFU daily } 2-4 \\
\text { weeks before delivery and then to } \\
\text { infant for } 12 \text { months }\end{array}$ & $\begin{array}{l}\text { No reduction } \\
\text { of eczema, but } \\
\text { reduction of } \\
\text { lgE-associated } \\
\text { eczema in the } \\
\text { probiotic group } \\
\text { at } 2 \text { years } \\
\text { No difference } \\
\text { between the } \\
\text { two groups at } \\
7 \text { years follow } \\
\text { up }\end{array}$ & No & No & $\begin{array}{l}\text { No differences } \\
\text { between the } \\
\text { groups when } \\
\text { evaluated by } \\
\text { spirometry } \\
\text { reversibility } \\
\text { test and FeNO } \\
\text { levels at } 7 \\
\text { years }\end{array}$ & 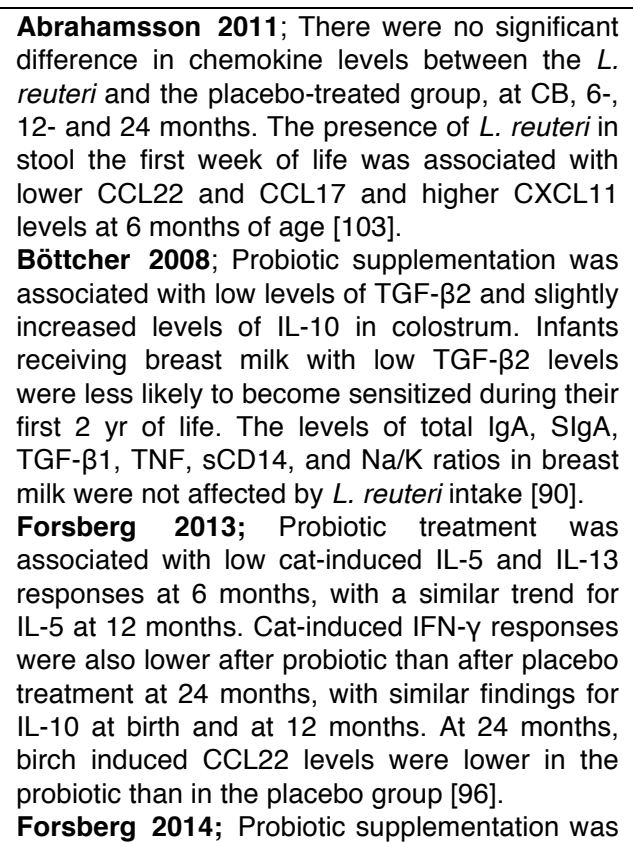 & $\begin{array}{l}\text { Abrahamsson 2009; The prevalence of } L \\
\text { reuteri was higher during the first year of } \\
\text { life in the stool samples from infants in the } \\
\text { probiotic group. The highest prevalence } \\
\text { was recorded at } 5 \text { to } 6 \text { days of age (82\% in } \\
\text { the treated vs } 20 \% \text { in the placebo group). } \\
\text { Supplementation affected neither the } \\
\text { prevalence nor the counts of bifidobacteria } \\
\text { or } C \text { difficile, except for higher counts of } \\
\text { bifidobacteria in the treated group at } 2 \\
\text { years. At } 12 \text { months the prevalence of } L \\
\text { reuteri was lower in breast-fed than } \\
\text { formula-fed infant. } L \text {. reuteri was isolated } \\
\text { from } 12 \% \text { and } 2 \% \text { of the colostrum } \\
\text { samples in the probiotic and placebo } \\
\text { group, respectively [75]. } \\
\text { Abrahamsson 2012; Probiotic } \\
\text { supplementation did not affect gut } \\
\text { microbiota diversity at } 1 \text { and } 12 \text { months, as } \\
\text { determined by 16S rDNA 454- } \\
\text { pyrosequencing [8]. }\end{array}$ \\
\hline
\end{tabular}




\begin{tabular}{|c|c|c|c|c|c|c|}
\hline & & & & & $\begin{array}{l}\text { associated with decreased LTA induced CCL4, } \\
\text { CXCL8, IL-1 } \beta \text { and IL- } 6 \text { responses at } 12 \text { months } \\
\text { and decreased CCL } 4 \text { and IL-1 } \beta \text { secretion at } 24 \\
\text { months. TLR2 and TLR } 4 \text { mRNA expression and } \\
\text { responses to LPS were not affected by probiotic } \\
\text { treatment [97]. }\end{array}$ & \\
\hline $\begin{array}{l}\text { Kukkonen et al, } 2007 \text { [25] and } \\
\text { Kuitunen et al, } 2009 \text { [36] } \\
\text { Any first degree relative with allergic } \\
\text { disease } \\
\text { Mix of L. rhamnosus GG and LC705 } \\
\text { (both } 5 \times 10^{9} \text { ) and B. breve Bb99 } \\
\text { and Proprionibacterium freudenreichii } \\
\text { ssp. shermani JS (both } 2 \times 10^{9} \text { ) plus } \\
\text { prebiotic galactooligosaccharides; } \\
\text { given twice daily to mother } 2-4 \text { weeks } \\
\text { before delivery and then to infant for } \\
6 \text { months }\end{array}$ & $\begin{array}{l}\text { Eczema } \\
\text { reduction in } \\
\text { the probiotic } \\
\text { group at } 2 \\
\text { years } \\
\text { No eczema } \\
\text { reduction at } \\
\text { five years }\end{array}$ & No & No & $\begin{array}{l}\text { No differences } \\
\text { in FeNO levels } \\
\text { between the } \\
\text { groups at } 5 \\
\text { years in a } \\
\text { randomized } \\
\text { subpopulation }\end{array}$ & $\begin{array}{l}\text { Kukkonen 2006; In the probiotic compared with } \\
\text { the placebo group, protective antibody } \\
\text { concentrations to Haemophilus influenzae type b } \\
\text { (Hib) occurred more frequently at } 6 \text { months, and } \\
\text { geometric mean IgG titres to Hib tended to be } \\
\text { higher. IgG titres to diphtheria and tetanus were } \\
\text { similar in the } 2 \text { groups [106]. } \\
\text { Marschan 2008; Infants receiving probiotic } \\
\text { bacteria had higher plasma levels of CRP, total } \\
\text { IgA, total IgE, and IL-10 than infants in the } \\
\text { placebo group [102]. } \\
\text { Kuitunen 2009; Probiotic supplementation } \\
\text { caused a gut mucosal inflammation with } \\
\text { decreased Hb values at } 6 \text { months, but Hb and } \\
\text { the other hematologic values were similar at } 2 \\
\text { years in the } 2 \text { groups [115]. } \\
\text { Kuitunen 2012; Probiotic supplementation was } \\
\text { associated with less IgA to casein and more IL- } \\
10 \text { in mature BM (3 month samples) but not in } \\
\text { colostrum, and with reduced colostral but not } \\
\text { mature BM TGF- } \beta 2 \text { levels. Probiotic } \\
\text { supplementation did not affect colostrum or } \\
\text { mature BM total IgA levels, nor levels of IgA } \\
\text { antibodies to CM, BLG and OVA [91]. } \\
\text { Savilathi 2015; Colostrum and } 3 \text { month BM } \\
\text { sCD14, human neutrophil peptide (HNP) 1-3 } \\
\text { and } \beta \text {-defensin } 2 \text { (HBD2) levels were not } \\
\text { affected by probiotic supplementation [123]. }\end{array}$ & $\begin{array}{l}\text { Kukkonen 2007; Faecal counts of all the } \\
\text { supplemented microbes were significantly } \\
\text { higher at } 3 \text { and } 6 \text { months. At } 2 \text { years, no } \\
\text { differences were observed between study } \\
\text { groups in faecal bacterial colonization } \\
\text { using agar culturing and PCR [25]. } \\
\text { Kukkonen 2009; Faecal IgA, a1-AT, TNF } \\
\text { and calprotectin was measured at the age } \\
\text { of } 3 \text { and } 6 \text { months. Probiotics tended to } \\
\text { augment faecal IgA and significantly } \\
\text { increased faecal a1-AT. High intestinal IgA } \\
\text { associated with reduced allergy risk [124]. }\end{array}$ \\
\hline $\begin{array}{l}\text { Kopp et al, } 2008 \text { [24] } \\
\text { Any first degree relative with allergic } \\
\text { disease } \\
\text { L. rhamnosus GG } 1 \times 10^{10} \text { CFU daily } \\
\text { given to mothers } 4-6 \text { weeks before } \\
\text { delivery and then to breastfeeding } \\
\text { mother for } 3 \text { months or to infant for } 6 \\
\text { months }\end{array}$ & $\begin{array}{l}\text { No at } 2 \text { years } \\
\text { Long term } \\
\text { outcomes not } \\
\text { reported }\end{array}$ & No & No & Not reported & $\begin{array}{l}\text { Kopp 2008; CBMC and PBMC of the } \\
\text { corresponding mother were isolated from cord } \\
\text { blood and peripheral blood ( } n=68) \text {. Cells were } \\
\text { stimulated with IL-2, } \beta \text {-lactoglobulin or LGG and } \\
\text { IFN- } \gamma \text {, IL-10 and IL-13 in the supernatants were } \\
\text { measured with ELISA. LGG induced IL-10 and } \\
\text { IFN- } \gamma \text { secretion in vitro, but independently of } \\
\text { probiotic supplementation [95]. }\end{array}$ & Not reported \\
\hline $\begin{array}{l}\text { Wickens et al, } 2008 \text { [27] and } \\
\text { Wickens et al, } 2013 \text { [38] }\end{array}$ & $\begin{array}{l}\text { Eczema } \\
\text { reduction in }\end{array}$ & $\begin{array}{l}\text { Lower } \\
\text { cumulative }\end{array}$ & No & $\begin{array}{l}\text { No differences } \\
\text { between the }\end{array}$ & $\begin{array}{l}\text { Prescott 2008; Neonates of mothers who } \\
\text { received } L \text {. rhamnosus but not } B \text {. lactis had }\end{array}$ & $\begin{array}{l}\text { Wickens 2008; L. rhamnosus }(71.5 \%) \text { was } \\
\text { more likely than } B \text {. lactis }(22.6 \%) \text { to be }\end{array}$ \\
\hline
\end{tabular}




\begin{tabular}{|c|c|c|c|c|c|c|}
\hline $\begin{array}{l}\text { Any first degree relative with allergic } \\
\text { disease } \\
\text { L. rhamnosus HN001 or B. lactis } \\
\text { HN019 } 1 \times 10^{10} \text { CFU daily from } 2-5 \\
\text { weeks before delivery and then to } \\
\text { infant directly for } 2 \text { years }\end{array}$ & $\begin{array}{l}\text { the } L . \\
\text { rhamnosus } \\
\text { group at } 2 \\
\text { years which } \\
\text { remained until } \\
6 \text { years } \\
\text { No benefit of } \\
B \text {. lactis }\end{array}$ & $\begin{array}{l}\text { sensitisatio } \\
\mathrm{n} \text { in the } \\
\text { group } \\
\text { receiving } L \text {. } \\
\text { rhamnosus } \\
\text { at } 6 \text { years } \\
\text { No benefit } \\
\text { of } B \text {. lactis }\end{array}$ & & $\begin{array}{l}\text { groups when } \\
\text { evaluated by } \\
\text { spirometry } \\
\text { reversibility } \\
\text { test and FeNO } \\
\text { levels at } 6 \\
\text { years }\end{array}$ & $\begin{array}{l}\text { higher CB IFN-Y levels, compared with the } \\
\text { placebo group. Colostrum TGF- } \beta 1 \text { levels were } \\
\text { increased after } B \text {. lactis supplementation, with a } \\
\text { similar tendency for } L \text {. rhamnosus. Increased } \\
\text { colostrum IgA levels were observed after both } B \text {. } \\
\text { lactis and } L \text {. rhamnosus administration. Neonatal } \\
\text { plasma sCD14 levels were lower in the } B \text {. lactis } \\
\text { group compared with the placebo group [93]. }\end{array}$ & $\begin{array}{l}\text { present in the faeces at } 3 \text { months, } \\
\text { although detection rates were similar by } 24 \\
\text { months [27]. }\end{array}$ \\
\hline $\begin{array}{l}\text { Niers et al, } 2009 \text { [29] and } \\
\text { Gorissen et al, } 2014 \text { [42] } \\
\text { Allergic disease of either parent and } \\
\text { in at least one sibling } \\
\text { Lactococcus lactis W58, B. lactis } \\
\text { W52 and B. bifidum W23 } 1 \times 10^{9} \\
\text { CFU each daily six weeks before } \\
\text { delivery and then directly to infant for } \\
12 \text { months }\end{array}$ & $\begin{array}{l}\text { Reduced } \\
\text { cumulative } \\
\text { incidence of } \\
\text { eczema in the } \\
\text { first three } \\
\text { months of life } \\
\text { No difference } \\
\text { at } 6 \text { years }\end{array}$ & No & No & Not reported & $\begin{array}{l}\text { Niers 2009; Reduced anti-CD2/CD28 induced } \\
\text { IL-5 and IL-13 levels were found in whole blood } \\
\text { cultures at } 3 \text { months of age in the probiotic } \\
\text { compared with the placebo group. The in vitro } \\
\text { lymphocyte proliferative response to either anti } \\
\text { CD2/CD28 or PHA did not differ between the } \\
\text { groups [29]. }\end{array}$ & $\begin{array}{l}\text { Niers 2009; Using T-RFLP, qPCR and } \\
\text { DGGE, L. lactis and B. bifidum but not } B \text {. } \\
\text { lactis were more easily detectable in the } \\
\text { probiotic compared with the placebo group } \\
\text { at } 3 \text { months of age [29] } \\
\text { Rutten 2015; Only minor and short term } \\
\text { differences in composition of microbiota } \\
\text { between the probiotic and placebo group } \\
\text { were found using } 16 S-23 S \text { rDNA } \\
\text { interspace region based profiling. Gut } \\
\text { microbiota development continued } \\
\text { between two and six years, then } \\
\text { approaching a more adult-like composition } \\
\text { [119]. }\end{array}$ \\
\hline $\begin{array}{l}\text { Kim et al, } 2010 \text { [30] } \\
\text { Any first degree relative with allergic } \\
\text { disease } \\
\text { B. bifidum BGN4, B. lactis AD011, } \\
\text { and L. acidophilus AD031( } 1.6 \times 10^{9} \\
\text { CFU of each daily) } 4-8 \text { weeks before } \\
\text { delivery, } 3 \text { months to breastfeeding } \\
\text { mother and then to infant from } 4 \text { to } 6 \\
\text { months }\end{array}$ & $\begin{array}{l}\text { Reduced } \\
\text { cumulative } \\
\text { incidence and } \\
\text { prevalence of } \\
\text { eczema at } 12 \\
\text { months } \\
\text { Long term } \\
\text { outcomes not } \\
\text { reported }\end{array}$ & $\begin{array}{l}\text { Not } \\
\text { reported }\end{array}$ & $\begin{array}{l}\text { Not } \\
\text { reported }\end{array}$ & Not reported & Not reported & Not reported \\
\hline $\begin{array}{l}\text { Ou et al, } 2012 \text { [22] } \\
\text { Maternal allergic disease } \\
\text { L. rhamnosus GG } 1 \times 10^{10} \mathrm{CFU} \text { daily } \\
\text { from second trimester and then } 6 \\
\text { months to mother if breastfeeding or } \\
\text { directly to infant }\end{array}$ & $\begin{array}{l}\text { No } \\
\text { Long term } \\
\text { outcomes not } \\
\text { reported }\end{array}$ & No & No & Not reported & $\begin{array}{l}\text { Ou 2012; There were no significant differences } \\
\text { in plasma IgE levels in the children at } 6,18 \text {, and } \\
36 \text { months of age, while mean plasma IgE was } \\
\text { higher in the cord blood of the LGG group. } \\
\text { Maternal plasma IL-13, IL-10, IFN- } \gamma \text {, CXCL10, } \\
\text { and TGF- } \beta \text { levels were not affected [22]. }\end{array}$ & Not reported \\
\hline Allen et al, 2014 [31] & No reduction & Not & No & Not reported & Not reported & Not reported \\
\hline
\end{tabular}




\begin{tabular}{|c|c|c|c|c|c|c|}
\hline $\begin{array}{l}\text { Any first degree relative with allergic } \\
\text { disease } \\
\text { L. salivaris CUL61, L. paracasei } \\
\text { CUL08, B. animalis ssp lactis CUL34 } \\
\text { and B. bifidum CUL20, } 10^{10} \text { CFU } \\
\text { daily in total starting } 2-4 \text { weeks } \\
\text { before delivery and then to the infant } \\
\text { for six months }\end{array}$ & $\begin{array}{l}\text { of eczema, but } \\
\text { a reduction of } \\
\text { lgE-associated } \\
\text { eczema at } 2 \\
\text { years of age in } \\
\text { the probiotic } \\
\text { group }\end{array}$ & reported & & & & \\
\hline \multicolumn{7}{|l|}{ POSTNATAL ADMINISTRATION } \\
\hline $\begin{array}{l}\text { Taylor et al, } 2007 \text { [32] and } \\
\text { Jensen et al, } 2012 \text { [39] } \\
\text { Maternal allergic disease } \\
\text { L. acidophilus (LAVRI-A1) } 3 \times 10^{8} \\
\text { CFU given within } 48 \text { hours, and then } \\
\text { for six months, directly to infant }\end{array}$ & $\begin{array}{l}\text { No reduction } \\
\text { at } 1 \text { year nor } \\
\text { at the or } 5 \\
\text { year follow-up }\end{array}$ & $\begin{array}{l}\text { No } \\
\text { Sensitisatio } \\
\text { n more } \\
\text { common in } \\
\text { the } \\
\text { probiotic } \\
\text { group at } 1 \\
\text { year, but } \\
\text { not at the } \\
\text { later follow- } \\
\text { ups }\end{array}$ & No & Not reported & $\begin{array}{l}\text { Taylor 2006; Infant cytokine (IL-5, IL-6, IL-10, } \\
\text { IL-13, TNF or TGF- } \beta \text { ) responses to TT, HDM, } \\
\text { OVA, BLG, SEB and PHA were measured at } 6 \\
\text { months of age. Probiotic supplementation was } \\
\text { associated with reduced production of IL-5 and } \\
\text { TGF- } \beta \text { in response to SEB stimulation, lower IL- } \\
10 \text { responses to TT vaccine antigen and reduced } \\
\text { TNF and IL-10 responses to HDM allergens [98]. } \\
\text { Taylor 2006; Mononuclear cell samples were } \\
\text { available from } 118 \text { infants and stimulated using } \\
\text { ligands for TLR2 and TLR4/CD14, finding no } \\
\text { effects of the probiotic supplementation on } \\
\text { cytokine responses. Circulating DC subset } \\
\text { frequencies and antigen presenting capacity } \\
\text { were similar between the groups [99]. } \\
\text { Taylor 2007; Infant regulatory T-cell function } \\
\text { was examined at } 6 \text { months. Probiotic } \\
\text { supplementation did not affect the proportion of } \\
\text { circulating CD4+CD25+CTLA4+ cells or FoxP3 } \\
\text { mRNA expression [100]. }\end{array}$ & $\begin{array}{l}\text { Taylor 2007; At } 1 \text { month of age, infants in } \\
\text { the probiotic group were almost twice as } \\
\text { likely to show culturable levels of } \\
\text { Lactobacillus species. By } 6 \text { months of age, } \\
\text { the rate of Lactobacillus colonization was } \\
\text { significantly higher in the probiotic than the } \\
\text { placebo group. The rates of colonization } \\
\text { with Bifidobacterium not affected by the } \\
\text { treatment [32]. }\end{array}$ \\
\hline $\begin{array}{l}\text { Soh et al, } 2009 \text { [33] and } \\
\text { Loo et al, } 2014 \text { [40] } \\
\text { Any first degree relative with allergic } \\
\text { disease, L. rhamnous LPR } 1 \times 10^{9} \\
\text { CFU and B. longum (BL999) } 6 \times 10^{8} \\
\text { CFU daily to infant (in infant formula) } \\
\text { for } 6 \text { months }\end{array}$ & $\begin{array}{l}\text { No reduction } \\
\text { at } 2 \text { or } 5 \text { years }\end{array}$ & No & No & Not reported & $\begin{array}{l}\text { Soh 2010; Compared with placebo, probiotic } \\
\text { supplementation improved hepatitis } B \text { (HepB) } \\
\text { surface antibody responses at } 12 \text { months in } \\
\text { subjects receiving monovalent doses of } \mathrm{HepB} \\
\text { vaccine at } 0,1 \text { month and a DTPa-HepB } \\
\text { combination vaccine at } 6 \text { months, but not those } \\
\text { who received } 3 \text { monovalent doses [104]. }\end{array}$ & Not reported \\
\hline
\end{tabular}




\section{West et al, 2009 [34]}

\section{West et al, 2013 [41]}

Mixed (2/3 with at least one first

grade relative with allergic disease)

L. paracasei ssp paracasei F19 $1 \mathrm{x}$

$10^{9} \mathrm{CFU}$ daily to infant (in infant

cereal) during weaning from 4-13

months
Reduced

cumulative

incidence of

eczema at 13

months

No difference

at 8 years
No

\begin{tabular}{|l|l} 
No & No
\end{tabular}

No

No

No differences

between the

groups when

evaluated by

spirometry

reversibility

test and FeNO

levels at 8

years
West 2008; Antibody concentrations to Hib capsular polysaccharide (HibPS), diphtheria toxin (D) and tetanus toxoid (T) before and after the second and third doses was measured. LF19 enhanced antibody concentrations to D and $T$, especially in infants breastfed less than 6 and $T$, especially in infants breasted less than 6 months. Conversely, breastfeeding duration influenced the anti-HibPS concentrations, with no effect by LF19 [105]

West 2009; At 13 months of age, the antiCD3/CD28 induced IFN- $y /$ IL4 mRNA ratio was higher in the probiotic compared with the placebo group [34].

West 2012; At 13 months of age, the antiCD3/CD28 induced IFN- $/ / L-2$ and IL-17A/L-2 mRNA ratios were higher in the probiotic than the placeco group, as was the TT induced IL17A expression. No differences were observed between the two groups at 5.5 months [101].

\section{West 2008: Using RAPD-PCR,}

L. paracasei ssp paracasei $\mathrm{F} 19$ was

detected in stool in $90 \%$ of the infants in

the probiotic group at 6 months and the

frequency remained high throughout the

intervention [105]. 